3

4 \section{intermediate water radiocarbon over the past 30,000 years \\ A high-resolution record of Southern Ocean}

\author{
Sophia K. V. Hines*, John R. Southon, Jess F. Adkins \\ * shines@caltech.edu (626) 395-8649
}

\begin{abstract}
The circulation of intermediate waters plays an important role in global heat and carbon transport in the ocean and changes in their distribution are closely tied to glacial-interglacial climate change. Coupled radiocarbon and U/Th measurements on deep-sea Desmophyllum dianthus corals allow for the reconstruction of past intermediate water ventilation. We present a high-resolution time series of Antarctic Intermediate Water radiocarbon from 44 corals spanning $30 \mathrm{ka}$ through the start of the Holocene, encompassing the transition into the Last Glacial Maximum (LGM) and the last deglaciation. Corals were collected south of Tasmania from water depths between 1430 and $1950 \mathrm{~m}$ with $80 \%$ of them between 1500 and $1700 \mathrm{~m}$, giving us a continuous record from a narrow depth range. The record shows three distinct periods of circulation: the MIS 3-2 transition, the LGM/Heinrich Stadial 1 (extending from 22 to $16 \mathrm{kyr}$ $\mathrm{BP}$ ), and the Antarctic Cold Reversal (ACR). The MIS 3-2 transition and the ACR are characterized by abrupt changes in intermediate water radiocarbon while the LGM time period generally follows the atmosphere at a constant offset, in support of the idea that the LGM ocean was at steady state for its ${ }^{14} \mathrm{C}$ distribution. Closer inspection of the LGM time period reveals a $40 \%$ jump at $\sim 19$ ka from an atmospheric offset of roughly $230 \%$ to $190 \%$, coincident with an observed 10-15 m rise in sea level and a southward shift of the Subantarctic and Polar Fronts, an abrupt change not seen in deeper records. During the ACR time period intermediate water radiocarbon is on average less offset from the atmosphere $(\sim 110 \%)$ and much more variable. This variability has been captured within the lifetimes of three individual corals with changes of up to $35 \%$ over $\sim 40$ years, likely caused by the movement of Southern Ocean fronts. This surprising result of relatively young and variable intermediate water radiocarbon during the ACR seems to go against the canonical idea of reduced circulation and ventilation in the south during this time period. However comparisons with other records from the Southern Ocean highlight zonal asymmetries, which can explain the deviation of our Tasmanian record from those in Drake Passage and the eastern Pacific. These signals seen in Tasmanian intermediate water $\Delta^{14} \mathrm{C}$ can also be found in Greenland ice core $\delta^{18} \mathrm{O}$ and East Asian monsoon strength. Throughout the LGM and the deglaciation, our Tasmanian intermediate water record is sensitive to times when the upper and lower cells of the meridional overturning circulation are more or less interconnected, which has important implications for the global climate system on glacialinterglacial time scales.
\end{abstract}




\section{1. Introduction}

The ocean is an important driver of global climate on a variety of timescales. Water has a

45 large heat capacity, which allows the oceans to transport significant amounts of sensible heat

46 from the tropics to the poles. Relative to its volume transport, intermediate water carries a large

47 amount of heat due to the large temperature difference between its formation and upwelling

48 regions (Talley, 2013; 2003). In addition to the ocean's direct effect on climate through heat

49 transport, the deep ocean stores 60 times more carbon than the atmosphere, so changes in ocean

50 circulation can have dramatic impacts on the global carbon cycle. Carbon is stored in the deep

51 ocean via the biological, solubility, and alkalinity pumps, and deeply regenerated $\mathrm{CO}_{2}$ returns to

52 the atmosphere when deep water upwells to the surface as part of the meridional overturning

53 circulation (Hain et al., 2014; Sigman et al., 2010).

54 One important tracer that is useful both for reconstructing mean and local ocean

55 circulation is radiocarbon. Radiocarbon $\left({ }^{14} \mathrm{C}\right)$ is cosmogenically produced in the atmosphere

56 where it is quickly converted to ${ }^{14} \mathrm{CO}_{2}$. Its 5730 -year half-life makes ${ }^{14} \mathrm{C}$ well suited as a tracer

57 for deep ocean circulation, which occurs on time scales of $\sim 1000$ years. The rate of change of

58 radiocarbon in the atmosphere is a balance between ${ }^{14} \mathrm{C}$ production (which is variable in time),

59 exchange with the ocean, and self-decay, which makes the radiocarbon value of the atmosphere a

60 very sensitive recorder of globally integrated ocean overturning. Reconstructions of ${ }^{14} \mathrm{C}$

61 production through time (Hain et al., 2014; Laj et al., 2002; Muscheler et al., 2004) are helpful

62 for disentangling these competing processes that imprint themselves on atmospheric $\Delta^{14} \mathrm{C}$.

63 However, production rate records are difficult to generate. Although mean ocean circulation

64 changes can help explain global shifts in climate, the specific regions involved and the timing of

65 regional changes is also crucial for understanding the mechanisms at work. Measurements of 
66 radiocarbon in the ocean are therefore important because they provide local information that can

67 be combined with the atmospheric record to generate a global understanding of how the ocean

68 behaves over millennial timescales.

69 We provide an intermediate water $\Delta{ }^{14} \mathrm{C}$ reconstruction from south of Tasmania in the

70 Indo-Pacific region of the Southern Ocean (Figure 1). In the modern ocean, Antarctic

71 Intermediate Water (AAIW) ventilates this region between $\sim 500$ and $1500 \mathrm{~m}$. Intermediate

72 waters are defined by extrema in salinity, and AAIW can be easily seen in the middle panel of

73 Figure 1a as the tongue of low-salinity water extending from the surface of the Southern Ocean

74 to between $\sim 500-1500 \mathrm{~m}$. At the sample location this water has a bomb-corrected $\Delta^{14} \mathrm{C}$ value of

75 around -150\% (Figure 1a, top panel), and underlying Circumpolar Deep Water (CDW) and

76 Antarctic Bottom Water (AABW) are more depleted in radiocarbon. The core of Pacific Deep

77 Water is marked by an oxygen minimum (Talley, 2013), and its return flow to the Southern

78 Ocean intersects with our sample location (Figure 1a, bottom panel). As Talley points out, the

79 modern meridional overturning circulation (MOC) does not consist of two separate cells stacked

80 on top of one another; instead both cells are intertwined (Figure 1d, top panel).

81 Through the application of simple box models, it has been shown that increasing the

82 meridional overturning strength and reducing the efficiency of the biological pump together are

83 able to accomplish the full glacial to interglacial $\mathrm{CO}_{2}$ change (Knox and McElroy, 1984;

84 Sarmiento and Toggweiler, 1984; Siegenthaler and Wenk, 1984). The configuration of the ocean

85 during the Last Glacial Maximum (LGM) was distinct from the modern (Curry and Oppo, 2005),

86 and it is thought that the ocean circulation was near steady state during this time. Benthic carbon

87 and oxygen isotope measurements show a shoaling of the boundary between the northern and

88 southern source water masses and a sharper gradient between them (Curry and Oppo, 2005; 
89 Lund et al., 2011). Recently, a mechanism has been proposed to move between the interglacial

90 and glacial circulation schemes. It builds on the observation that the boundary between the upper

91 and lower cells is defined by the switch between positive and negative buoyancy forcing at the

92 surface of the Southern Ocean, and that this location generally aligns with the summertime sea

93 ice edge (Ferrari et al., 2014). To first order, isopycnals have a constant slope across the

94 Southern Ocean and are flat in the rest of the ocean basin, so it is possible to calculate the depth

95 of the boundary between deep cells based on the high latitude buoyancy forcing. In the modern

96 ocean, this boundary sits at around $2200 \mathrm{~m}$, which is deep enough for the rough topography at

97 the bottom of the ocean to effectively mix water between the cells. Expanded sea ice during the

98 LGM shoals this boundary out of the rough region and allows for separation between the upper

99 and lower cells (Figure 1d)(Ferrari et al., 2014).

100 In this paper, we use the results of age screening deep-sea corals from the Caltech

101 collection to select samples for a continuous well-dated time series of $\Delta^{14} \mathrm{C}$ from a narrow depth

102 range in the region south of Tasmania. This high-resolution time series is then used to examine

103 glacial climate and the behavior of the Southern Ocean during the deglaciation. Our sample

104 location lies within the modern and glacial upper cell but near its lower boundary, so it is quite

105 sensitive to the interconnectedness of the meridional overturning circulation. We assess this

106 interconnectedness by comparing our Tasmanian intermediate water $\Delta^{14} \mathrm{C}$ record to other

107 Southern Ocean records from different depths as well as atmospheric $\mathrm{CO}_{2}$. 

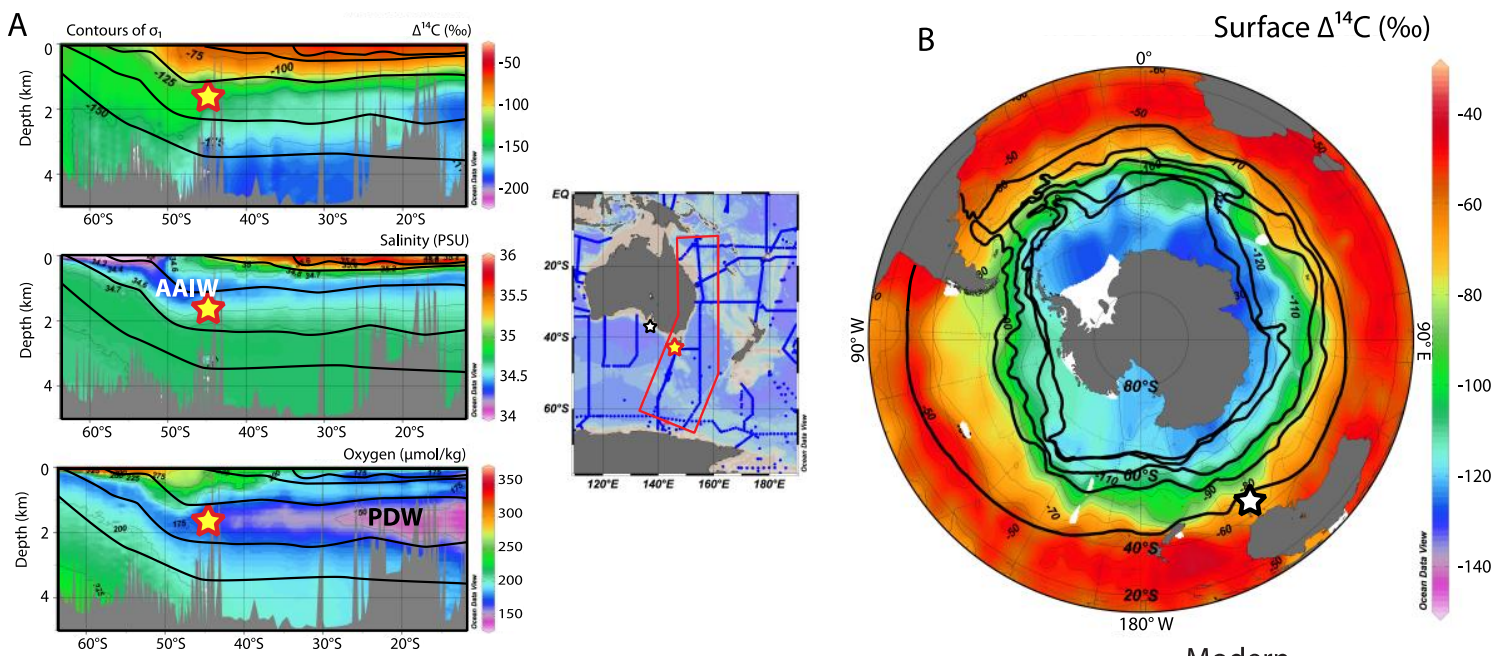

$$
\text { c }
$$
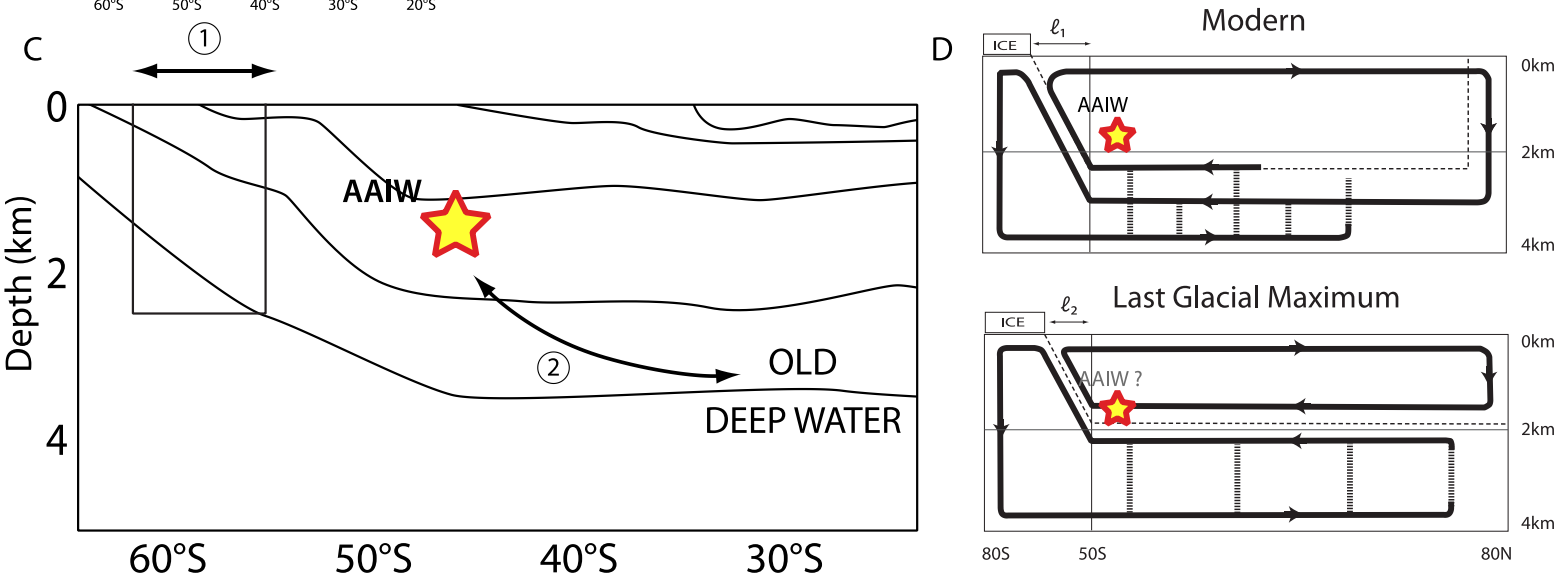

Figure 1. Hydrography for the broader region around our sample location. A) Sections of bombcorrected $\Delta{ }^{14} \mathrm{C}$ (top), salinity (middle), and oxygen (bottom) from $\sim 65^{\circ} \mathrm{S}-10^{\circ} \mathrm{S}$ for the region marked on the inset map (Key et al., 2004). Sample location marked with a yellow star. Thick black contour lines are isopycnals $\left(\sigma_{1}\right)$. In this region, tracers largely move along density surfaces. Map to the right shows the location of the sections, the Tasmanian coral location (yellow star) and the location of core MD-03-2611 (black star). B) Surface map of bombcorrected $\Delta^{14} \mathrm{C}$ for the whole Southern Ocean. Thick black lines mark the positions of the major Southern Ocean fronts (from furthest north to furthest south: Subtropical Front (STF), Subantarctic Front (SAF), Polar Front (PF), Southern ACC Front (SACCF), and the Southern Boundary (SB)). C) Schematic Southern Ocean section with contours of density (taken from panel A). Coral location is marked with yellow star, and arrows show the two main ways to change radiocarbon values. D) Schematic of modern and glacial meridional overturning circulation with coral location marked with yellow star (adapted from (Ferrari et al., 2014)). In the modern, upper and lower cells are intertwined whereas in the glacial, cells are separated. This is due to increased sea ice extent (note: $l_{1}$ in the upper panel is greater than $l_{2}$ in the lower panel). 


\section{Methods}

Deep-sea corals used in this study were collected from seamounts south of Tasmania

$128\left(43^{\circ} \mathrm{S}-47^{\circ} \mathrm{S} 144^{\circ} \mathrm{E}-152^{\circ} \mathrm{E}\right)$ during cruise $\mathrm{TN}-228$ in $2008-2009$ on the $\mathrm{R} / \mathrm{V}$ Thompson using the

129 remotely operated deep submergence vehicle JASON. During this cruise over 10,000 deep-sea

130 corals were collected from between $898-2395 \mathrm{~m}$. All corals used for the construction of this time

131 series were the scleractinian azooxanthellate Desmophyllum dianthus. The time series presented

132 here encompasses samples from 1430-1950 m with 80\% of samples between 1500 and $1700 \mathrm{~m}$

133 (marked with a star in Figure 1a sections).

134 Previous reconnaissance radiocarbon dating (Thiagarajan et al., 2013) was performed at

135 the National Ocean Sciences Accelerator Mass Spectrometry Laboratory at the Woods Hole

136 Oceanographic Institute following the method of Burke et al. (Burke et al., 2010) using an

137 Elemental Analyzer. Additional radiocarbon age screening was performed at the UC Irvine Keck

138 Carbon Cycle AMS facility following the 'rapid survey' method of Bush et al. (Bush et al.,

139 2013). Reconnaissance ${ }^{14} \mathrm{C}$ dates were converted into calendar ages using IntCal13 and the Calib

1407.0 software and reservoir age offsets according to Thiagarajan et al. (Thiagarajan et al., 2013)

141 for consistency (1250 yr for the Holocene and $1900 \mathrm{yr}$ for all samples older than $10 \mathrm{kyr}$.)

142 In preparation for U/Th and high-precision radiocarbon dating, all coral samples were

143 physically and chemically cleaned following previously established methods (Cheng et al., 2000;

144 Shen and Boyle, 1988). U/Th dating was performed using previously established methods

145 (Cheng et al., 2000; Robinson et al., 2007). Approximately $100 \mathrm{mg}$ of coral was weighed,

146 dissolved in Seastar $\mathrm{HNO}_{3}$, and spiked with a mixed ${ }^{229} \mathrm{Th}^{236} \mathrm{U}$ spike. Uranium and thorium

147 were separated from the rest of the coral matrix by iron co-precipitation and anion exchange

148 chromatography. Purified U and Th fractions were dried and re-dissolved in 5\% Seastar nitric 
149 acid and measured on a Thermo Scientific Neptune MC-ICPMS. Bracketing CRM-145 standards

150 for uranium and SGS standards for thorium were used to correct for instrumental drift, mass bias

151 and gain. Uranium samples were intensity matched to within $\sim 10 \%$ of the CRM- 145 standard for

$152{ }^{234} \mathrm{U}$, which was measured on the center position secondary electron multiplier with a retarding

153 potential quadruple to reduce scattered ion effects. ${ }^{235} \mathrm{U},{ }^{236} \mathrm{U}$, and ${ }^{238} \mathrm{U}$ were measured on

154 faraday cups with $10^{10} \mathrm{ohm}$ resistors. ${ }^{229} \mathrm{Th}$ and ${ }^{230} \mathrm{Th}$ were measured on channeltron ion counters

155 and ${ }^{232} \mathrm{Th}$ was measured on a faraday cup with a $10^{10} \mathrm{ohm}$ resistor. Four procedural blanks were

156 run with each set of samples and the average of the blank values was subtracted from each of the

157 samples. Samples and standards were also corrected for instrumental blank using the average of

158 bracketing 5\% Seastar nitric used to dilute samples and standards. Samples were corrected for

159 initial thorium using a ${ }^{230} \mathrm{Th} /{ }^{232} \mathrm{Th}$ atom ratio of $80 \pm 80 \times 10^{-6}$ (Cheng et al., 2000).

160 High-precision ${ }^{14} \mathrm{C}$ dating was performed at the Keck Carbon Cycle AMS facility at UC

161 Irvine. Approximately $11 \mathrm{mg}$ of cleaned coral was weighed into a $3 \mathrm{~mL}$ rubber septum top vial

162 and leached in $0.01 \% \mathrm{HCl}$ to remove $10 \%$ of the coral mass. Samples were then dried, evacuated

163 and hydrolyzed in phosphoric acid. The resulting $\mathrm{CO}_{2}$ was purified and graphitized with $\mathrm{H}_{2}$ and

164 an iron catalyst (Santos et al., 2007). Graphite was pressed into aluminum targets for ${ }^{14} \mathrm{C}$ analysis

165 on the accelerator mass spectrometer. Measured radiocarbon activities are normalized for mass-

166 dependent fractionation using $\delta^{13} \mathrm{C}$ values measured on the $\mathrm{AMS}$, and normalized to a $\delta^{13} \mathrm{C}_{\mathrm{PDB}}$

167 value of $-25 \%$. Radiocarbon activities are reported as fraction modern $\left(\mathrm{F}_{\mathrm{m}}\right)$ relative to $95 \%$ of

168 the activity of NBS oxalic acid standard in the year 1950 (normalized to $\delta^{13} \mathrm{C}_{\mathrm{PDB}}=-19 \%$ ).

169 Fraction modern is converted to a ${ }^{14} \mathrm{C}$ age using the formula ${ }^{14} \mathrm{C}$ age $=-8033 \ln \left(\mathrm{F}_{\mathrm{m}}\right)$. Radiocarbon

170 blanks measured on ${ }^{14} \mathrm{C}$-dead deep-sea corals tend to be larger and more variable than those

171 measured on ${ }^{14} \mathrm{C}$-dead calcite (e.g. (Adkins et al., 2002; Eltgroth et al., 2006)). Therefore, corals 
172 are background corrected using the average and standard deviation of radiocarbon values

173 measured on replicate samples $(n=8)$ of a "radiocarbon dead" deep-sea coral $\left(\mathrm{F}_{\mathrm{m}}=\right.$

$1740.0034 \pm 0.0007)$ with a U/Th age of $205,000 \pm 3000 \mathrm{yr}$.

175 Intermediate water $\Delta^{14} \mathrm{C}$ values were reconstructed using measured U/Th ages and high-

176 precision radiocarbon dates on coral samples according to the expression:

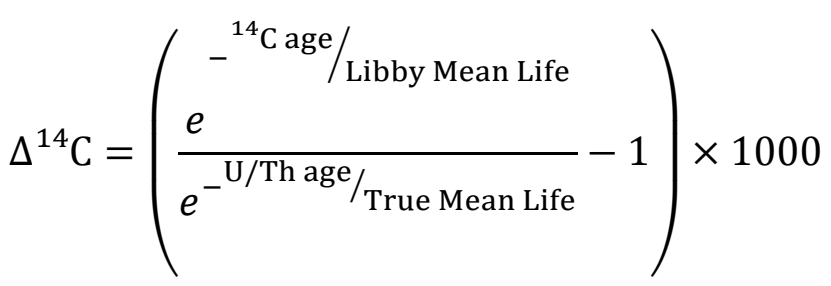

177 where the Libby Mean Life is $8033 \mathrm{yr}$ and the True Mean Life is $8266 \mathrm{yr}$ (Stuiver and Polach,

178 1977). This $\Delta{ }^{14} \mathrm{C}$ value corrects for the time elapsed since each coral sample grew, thereby

179 extracting the $\Delta{ }^{14} \mathrm{C}$ value of the water it grew in, relying on the assumption that both the carbon

180 isotope system and the U/Th isotope system have remained closed. For corals with top, middle,

181 and bottom dates, a single U/Th age is measured on the top of the coral and middle and bottom

182 dates are inferred using measured distances between subsamples and a growth rate of $1 \mathrm{~mm} /$ year

183 (Adkins et al., 2004). Age errors for middle and bottom subsamples are assigned to be 50 years.

184 Error in the $\Delta^{14} \mathrm{C}$ value incorporates both error from U/Th dating and ${ }^{14} \mathrm{C}$ dating. Because

185 calculating $\Delta{ }^{14} \mathrm{C}$ involves taking a ratio of exponentials, error in either of the dates can cause the

186 total error to greatly increase (Supplemental Figure 1). When comparing these intermediate

187 water $\Delta^{14} \mathrm{C}$ values to the contemporaneous atmosphere, it is most appropriate to transform the

$188 \Delta \Delta^{14} \mathrm{C}$ data into epsilon values, which are similar to $\Delta \Delta{ }^{14} \mathrm{C}$. Epsilon values are the proper way of

189 differencing delta values and are calculated by converting the $\Delta{ }^{14} \mathrm{C}$ of each sample and the

190 contemporaneous atmosphere into ratios, and taking the ratio of the ratios: 


$$
\varepsilon=\left(\left[\frac{\frac{\Delta^{14} C_{\text {sample }}}{1000}+1}{\frac{\Delta^{14} C_{\text {atm }}}{1000}+1}\right]-1\right) \times 1000
$$

191 Epsilon is a more correct measure of past ocean circulation changes than $\Delta \Delta^{14} \mathrm{C}$ because it takes

192 into account changes in atmospheric $\Delta^{14} \mathrm{C}$ value itself. It is therefore the parameter that stays

193 constant (for sufficiently slow ${ }^{14} \mathrm{C}$ production changes) if ocean circulation does not change.

\section{3. Results}

195 Radiocarbon age screening reveals patterns consistent with those published by

196 Thiagarajan et al. (Thiagarajan et al., 2013) (Figure 2). 97 corals were selected for ${ }^{14} \mathrm{C}$ screening

197 from between $1390-1748 \mathrm{~m}$, and 162 corals were selected from between $2004-2739 \mathrm{~m}$.

198 Previously, an additional 249 samples from between the depths of $899-2395$ m were measured

199 by Thiagarajan et al. (Thiagarajan et al., 2013). All of the corals deeper than $2000 \mathrm{~m}$ are

200 Holocene-age with most younger than 5000 yr. There is an abundance peak with a greater depth

201 range $(1450-1950 \mathrm{~m})$ that roughly coincides with the ACR and HS1. The LGM on the other

202 hand has a much more restricted depth range, with most corals between $1450-1575$ m. Average

203 uncertainties were $300{ }^{14} \mathrm{C}$-years for samples screened at NOSAMS using the EA method, and

$204500{ }^{14} \mathrm{C}$-years for samples screened at UC Irvine using the 'rapid survey' method. The average

205 offset between screened ages (converted into calendar age) and U/Th ages is $1500 \mathrm{yr}$. This

206 discrepancy is most likely the result of our choice of reservoir age through time, in addition to

207 changes in ventilation age. 


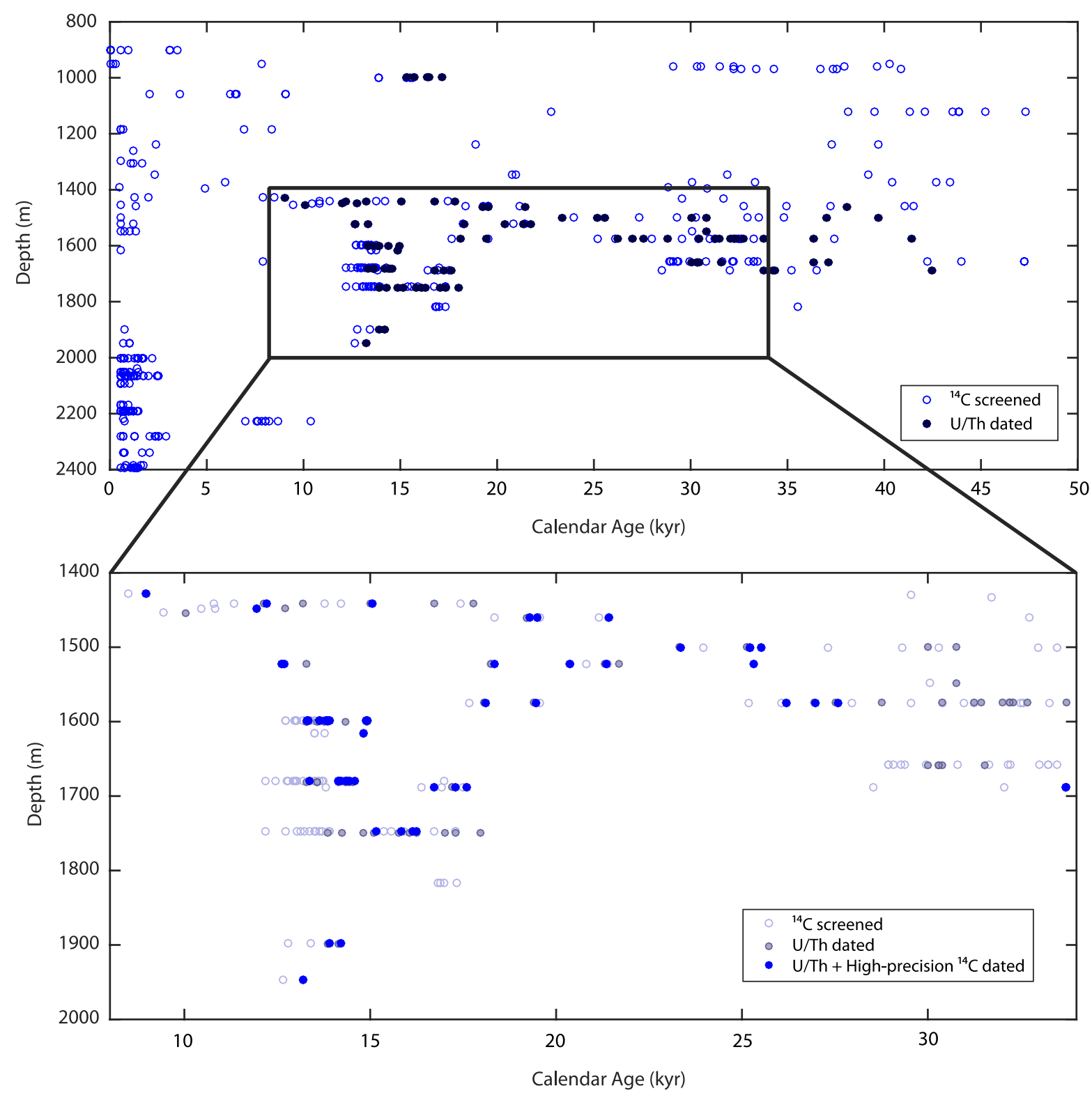

Figure 2. Age-depth distribution for ${ }^{14} \mathrm{C}$ screened corals. Upper panel shows all screened corals (blue open circles; $n=508$ ) and individuals that were selected for $U / T h$ dating (blue filled circles; $\mathrm{n}=112$ ). Lower panel is an expanded view of the boxed region in the upper panel. In the lower panel, ${ }^{14} \mathrm{C}$ screened and U/Th dated corals from the upper panel are shown in lighter blue, and filled blue circles represent the subset of U/Th dated samples that were also high-precision

$214{ }^{14} \mathrm{C}$ dated $(\mathrm{n}=44)$.

215 In order to have a sufficient age range and sampling frequency for the $\Delta^{14} \mathrm{C}$ time series,

216103 individual corals were U/Th dated (Supplementary Table 1). Samples were selected for U/Th

217 dating based on their depth and reconnaissance age. Dates were assessed based on two main 
218 criteria: the amount of ${ }^{232} \mathrm{Th}$, which increases errors due to uncertainty in the initial ${ }^{232} \mathrm{Th} /{ }^{230} \mathrm{Th}$

219 ratio, and the initial $\delta^{234} U$ value, which provides information about whether or not the sample

220 has behaved as a closed system (a primary assumption for U/Th dates). If the sample has

221 behaved as a closed system, then the calculated initial $\delta^{234} U\left(\delta^{234} U_{\text {init }}=\delta^{234} U_{\text {meas }} e^{\lambda t}\right)$ should be

222 within error of the marine $\delta^{234} \mathrm{U}$ value. 14 samples had ${ }^{232} \mathrm{Th}$ concentrations above the cutoff

223 value of $2000 \mathrm{ppt}$, and 3 samples had $\delta^{234} \mathrm{U}_{\text {init }}$ values that were non-marine using the selection

224 criteria from IntCa109, which is defined as $147 \pm 7 \%$ for corals younger than $17 \mathrm{kyr}$ and

$225141.7 \pm 7.8 \%$ for corals older than $17 \mathrm{kyr}$ (Reimer et al., 2009). The average relative error for all

226 dates was $6.64 \%$ and the average relative error for all samples that met the ${ }^{232} \mathrm{Th}$ and $\delta^{234} \mathrm{U}$

227 criteria was 5.26\%. Procedural blanks account for $0.05 \%$ or less of the total error for ${ }^{238} \mathrm{U}$ and

$228{ }^{234} \mathrm{U}, 0.14 \%$ of the total error for ${ }^{230} \mathrm{Th}$, and $1.97 \%$ of the total error for ${ }^{232} \mathrm{Th}$, with average

229 values of $38 \mathrm{fmol}$ for ${ }^{232} \mathrm{Th}$ and 0.29 pmol for ${ }^{238} \mathrm{U}$.

230 Out of the 103 individual corals that were U/Th dated, 44 were selected for high-

231 precision radiocarbon dating. Keeping with the goal of creating a high-resolution continuous

232 time series, samples were selected for high-precision radiocarbon dating based on their U/Th

233 ages, ${ }^{232} \mathrm{Th}$ concentrations, and uranium isotope values. Of these 44 samples, eight were

234 subsampled for top, middle, and bottom dates (Figure 4). Average relative errors radiocarbon

235 dates were $2.7 \%$ for samples less than $15,000{ }^{14} \mathrm{C}$-years, 3.6\% for samples between 15,000 -

$23620,000{ }^{14} \mathrm{C}$-years, $4.6 \%$ for samples between $20,000-25,000{ }^{14} \mathrm{C}$-years, and $8.4 \%$ o for samples

237 older than $25,000{ }^{14} \mathrm{C}$-years. 


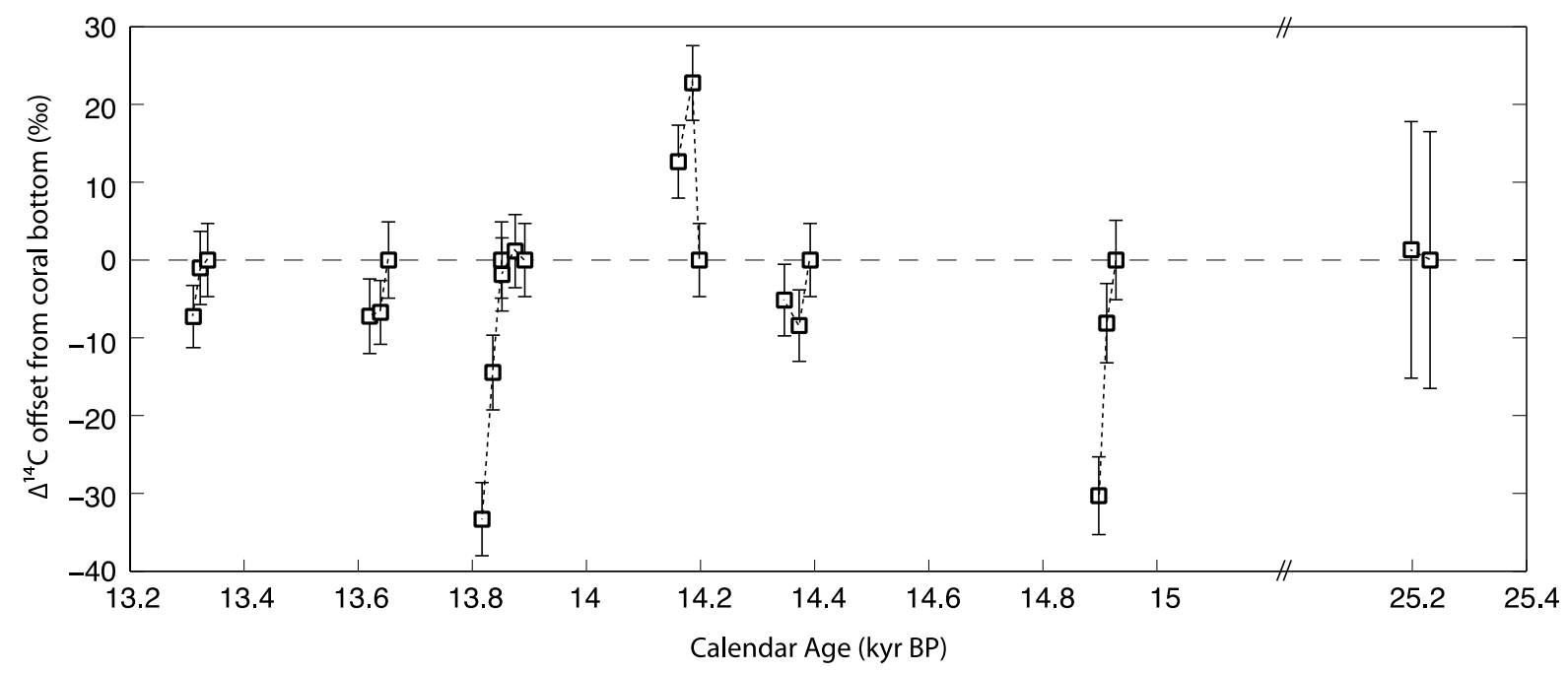

Figure 3. Changes in $\Delta^{14} \mathrm{C}$ over the lifetime of single deep-sea coral specimens. Seven corals were sub-sampled for top-middle-bottom ${ }^{14} \mathrm{C}$ dates and one for top-bottom ${ }^{14} \mathrm{C}$ dates. Calculated $\Delta^{14} \mathrm{C}$ values are plotted as differences from the bottom of the coral with $1 \sigma$ error bars based only on uncertainty from radiocarbon dating. Of these eight corals, three show distinguishable changes in $\Delta^{14} \mathrm{C}$ over the lifetime of the coral, two show no change, and three show slight changes that are not resolvable within error. (Note break in X-axis between 15 and $25.2 \mathrm{ka}$ ).

The $\Delta^{14} \mathrm{C}$ dataset presented here is the highest resolution record that has been produced for this time in the Southern Ocean. It contains $68{ }^{14} \mathrm{C}$ dates on 44 individual corals between 9000-33,790 yr with an average sampling resolution of $575 \mathrm{yr}$ (average resolution of $295 \mathrm{yr}$ between 9000 - 15,170 yr and 590 yr between 15,830 - 27,580 yr) (Figure 4). Eight of these 44 corals were also subsampled for even higher resolution radiocarbon dating during times of increased $\Delta^{14} \mathrm{C}$ variability, and three of these corals reveal resolvable changes in intermediate water radiocarbon occurring on decadal timescales (Figure 3; depicted as separate $\Delta^{14} \mathrm{C}$ points connected by lines on subsequent figures).

The full record can be broken up into three main segments based on chronology and $\Delta^{14} \mathrm{C}$ behavior during these periods: the Marine Isotope Stage (MIS) $3-2$ transition, the LGM/early HS1, and the ACR. The MIS 3 - 2 transition segment is characterized by one large drop in intermediate water radiocarbon of $\sim 250 \%$ starting at $27.6 \mathrm{ka}$. This drop is followed by a period 
257 of intermediate water variability and then a gap between $23.6-21.5 \mathrm{ka}$. Between $21.5-16 \mathrm{ka}$,

258 the LGM/early HS1 segment, intermediate waters roughly follow the atmosphere with an offset

259 of around $200 \%$ (with a $\sim 40 \%$ jump at around $19 \mathrm{ka}$ ). Then there is an 800 -year gap in the

260 record, after which intermediate waters are on average less offset from the atmosphere but far

261 more variable. This final ACR segment contains three corals that record abrupt changes in

262 intermediate radiocarbon within their lifetimes (Figure 3). There is a drop of 30\% at $14.9 \mathrm{ka}$, a

263 rise of $23 \%$ at $14.2 \mathrm{ka}$, and a drop of $40 \%$ at $13.9 \mathrm{ka}$ (Figure 4).

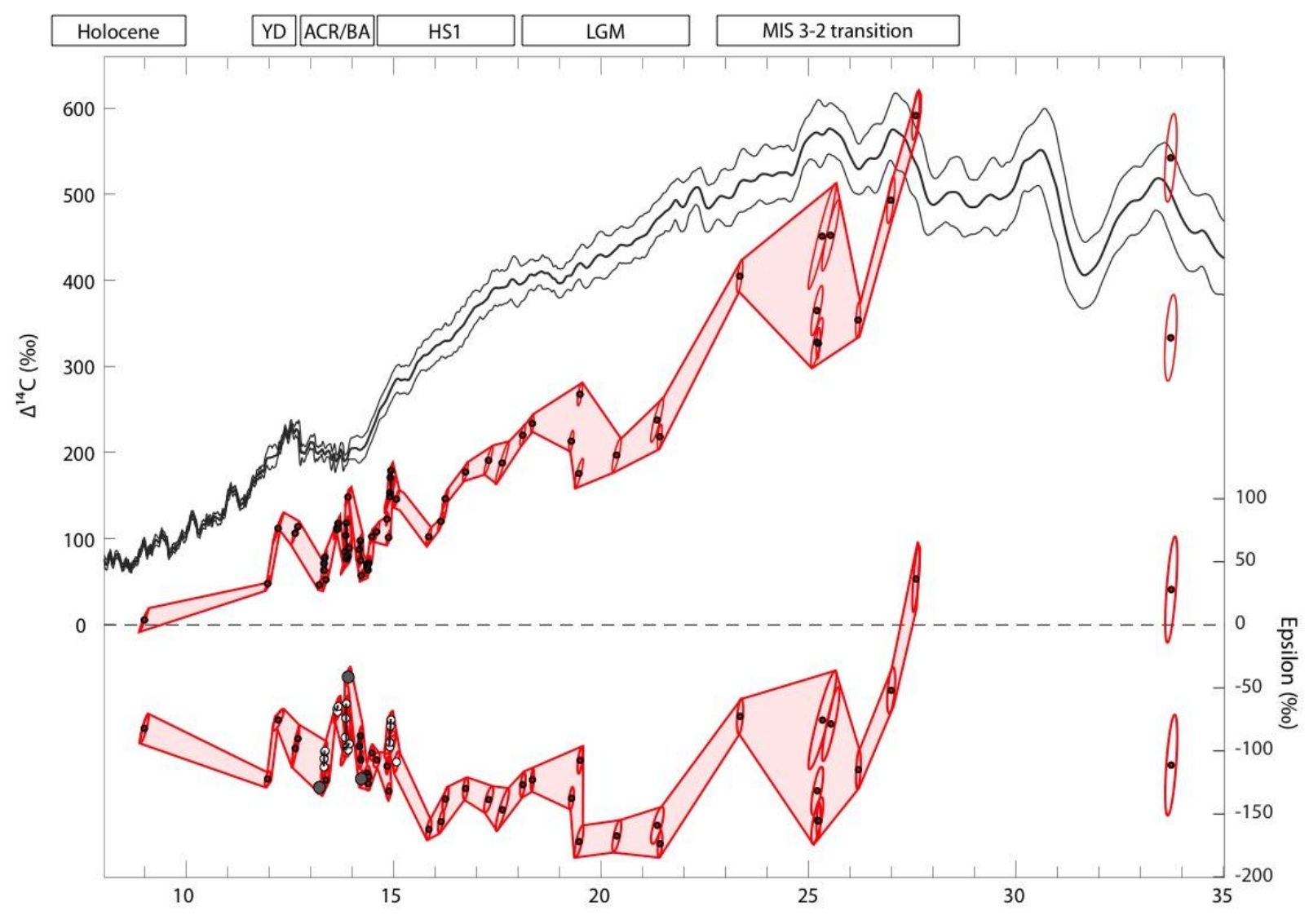

264

265

266

267

268

269

270

Calendar Age (kyr BP)

Figure 4. A) Tasmanian $\Delta^{14} \mathrm{C}$ record plotted with IntCal13 atmospheric $\Delta^{14} \mathrm{C}$ record, and B) converted into epsilon values. Error ellipses represent $1 \sigma$ correlated U/Th and $\Delta^{14} \mathrm{C}$ errors. For epsilon values, these ellipses also take into account uncertainty in the IntCal13 atmospheric $\Delta^{14} \mathrm{C}$ record. Despite coming from between 1442 and $1947 \mathrm{~m}$, epsilon variability between $\sim 15-13 \mathrm{ka}$ is not depth dependent. The deepest samples (at 1947 and $1898 \mathrm{~m}$ ) are shown in panel B with dark gray filled circles, and they encompass nearly the full range in epsilon (including the 
271 highest point). The shallowest samples (at 1442 and $1599 \mathrm{~m}$ ) are shown with white circles. 25 of

272 the 30 samples from this time interval come from depth range of less than $100 \mathrm{~m}(1599-1680 \mathrm{~m})$.

\section{4. Discussion}

The Southern Ocean is a region where deep water upwells to the surface and exchanges

275 with the atmosphere making it important to global climate. The Southern Ocean is also important

276 in setting atmospheric $\mathrm{CO}_{2}$ values over glacial-interglacial timescales (Sarmiento and

277 Toggweiler, 1984). In the Southern Ocean, surface $\Delta^{14} \mathrm{C}$ values are generally aligned with

278 isopycnals and fronts (Figure 1b). This is the result of Southern Ocean overturning, where the

279 oldest water upwells close to Antarctica, and the residence time of water at the surface, which is

280 not long enough for the full exchange of carbon isotopes. This leads to a meridional surface

281 gradient in $\Delta{ }^{14} \mathrm{C}$ with more negative values closest to Antarctica (Figure 1b). When water leaves

282 the surface of the Southern Ocean, the surface $\Delta^{14} \mathrm{C}$ gradient is transformed into a vertical

283 gradient (Figure 1a). Because of this pattern, there are two main mechanisms to generate changes

284 in intermediate water $\Delta{ }^{14} \mathrm{C}$ at our sampling location—one of them able to produce abrupt

285 changes on annual to decadal timescales and the other tending to produce more gradual changes

286 over centennial to millennial timescales (Figure 1c). On short timescales, meridional shifts in the

287 position of Southern Ocean fronts can change the $\Delta^{14} \mathrm{C}$ value of the water ventilating a particular

288 region (Figure 1c; mechanism 1). On longer timescales, $\Delta^{14} \mathrm{C}$ changes could also reflect the

289 degree of mixing between Tasmanian intermediate water and older Pacific deep water below and

290 to the north (Figure 1c; mechanism 2). The amount of mixing between Tasmanian intermediate

291 water and older, deeper water masses also dictates how responsive intermediate waters will be to

292 changes in atmospheric $\mathrm{CO}_{2}$, since older deep waters carry the majority of regenerated $\mathrm{CO}_{2}$. In

293 general, the positions of fronts in the Southern Ocean are dictated by bathymetry (Graham et al., 
294 2012). However in the absence of strong bathymetric features, fronts are less constrained and

295 respond to the position of Southern Ocean westerly winds (Sallée et al., 2008). This latter

296 scenario is the case for the Subantarctic and Polar Fronts in the region south of Tasmania,

297 between which Antarctic Intermediate Water is formed.

\subsection{LGM STEADY STATE AND EARLY FRONTAL SHIFTS}

Beginning at $21.5 \mathrm{ka}$, the Tasmanian coral $\Delta{ }^{14} \mathrm{C}$ record generally follows the atmosphere

300 at a constant offset. This trend can be easily seen by converting the $\Delta^{14} \mathrm{C}$ record into epsilon

301 units. Between $\sim 21.5$ and $19 \mathrm{ka}$, intermediate waters have an epsilon of $\sim-170 \%$. After an

302 abrupt jump of $\sim 40 \%$ at $19 \mathrm{ka}$, intermediate water $\Delta{ }^{14} \mathrm{C}$ continues to follow the atmosphere, now

303 with epsilon values of around $-130 \%$. Correcting the IntCal13 atmospheric $\Delta{ }^{14} \mathrm{C}$ reconstruction

304 for the contribution from production rate changes, the residual atmospheric $\Delta^{14} \mathrm{C}$ is flat across

305 most of the LGM, consistent with an ocean-atmosphere system at steady state (Hain et al.,

306 2014)(Figure 5a). Together, the consistency between the atmosphere and the coral $\Delta^{14} \mathrm{C}$ and the

307 constant value of production-corrected atmospheric $\Delta^{14} \mathrm{C}$ imply that the ocean was at or near

308 steady state during the LGM.

309 The jump in intermediate water radiocarbon at $\sim 19 \mathrm{ka}$ is a conspicuous departure from

310 the otherwise steady-state-like conditions of the LGM. This timing is coincident with $10-15 \mathrm{~m}$

311 of sea level rise measured using a series of sediment cores off the northern coast of Australia

312 (Yokoyama et al., 2000). It also corresponds to an abrupt and permanent poleward shift of the

313 Subantarctic (SAF) and Polar Fronts (PF) as shown by foram faunal assemblage data from a core

314 located south of Australia (MD03-2611, 36 $43.8^{\prime}$ S, 136 32.9' E, 2420 m; Figure 5d) (De

315 Deckker et al., 2012). A southward shift of the Subantarctic and Polar Fronts would lead to a rise

316 in intermediate water $\Delta{ }^{14} \mathrm{C}$ south of Tasmania. The decrease in subpolar foraminifera beginning 
317 at $19 \mathrm{ka}$ also marks the first appearance of subtropical fauna, which dominate the rest of the 318 deglaciation.

319 Based on the relative timing of Northern and Southern Hemisphere ice sheet and

320 mountain glacier retreat following the Last Glacial Maximum, it is thought that the sea level rise

321 at $\sim 19$ ka originated from ice sheet retreat in the north (Clark et al., 2009). This influx of fresh

322 water to the North Atlantic caused a reduction in the strength of the Atlantic meridional

323 overturning circulation (AMOC) and initiated warming in the Southern Hemisphere via the

324 bipolar seesaw (Broecker, 1998; Shakun et al., 2012). Atmospheric models show that the ITCZ

325 and other aspects of tropical circulation responds to changes in extratropical temperature,

326 shifting toward the warmer hemisphere (Kang et al., 2008). Shifts in the position of the ITCZ can

327 in turn affect other atmospheric wind belts, shifting them in the same direction (Ceppi et al.,

328 2013). This is consistent both with our $\Delta{ }^{14} \mathrm{C}$ record and with foram assemblages from south of

329 Australia (De Deckker et al., 2012). Our data is consistent with melting of Northern Hemisphere

330 ice sheets reducing the strength of the AMOC, which shifted atmospheric winds to the south and

331 caused a southward shift in Southern Ocean fronts. 


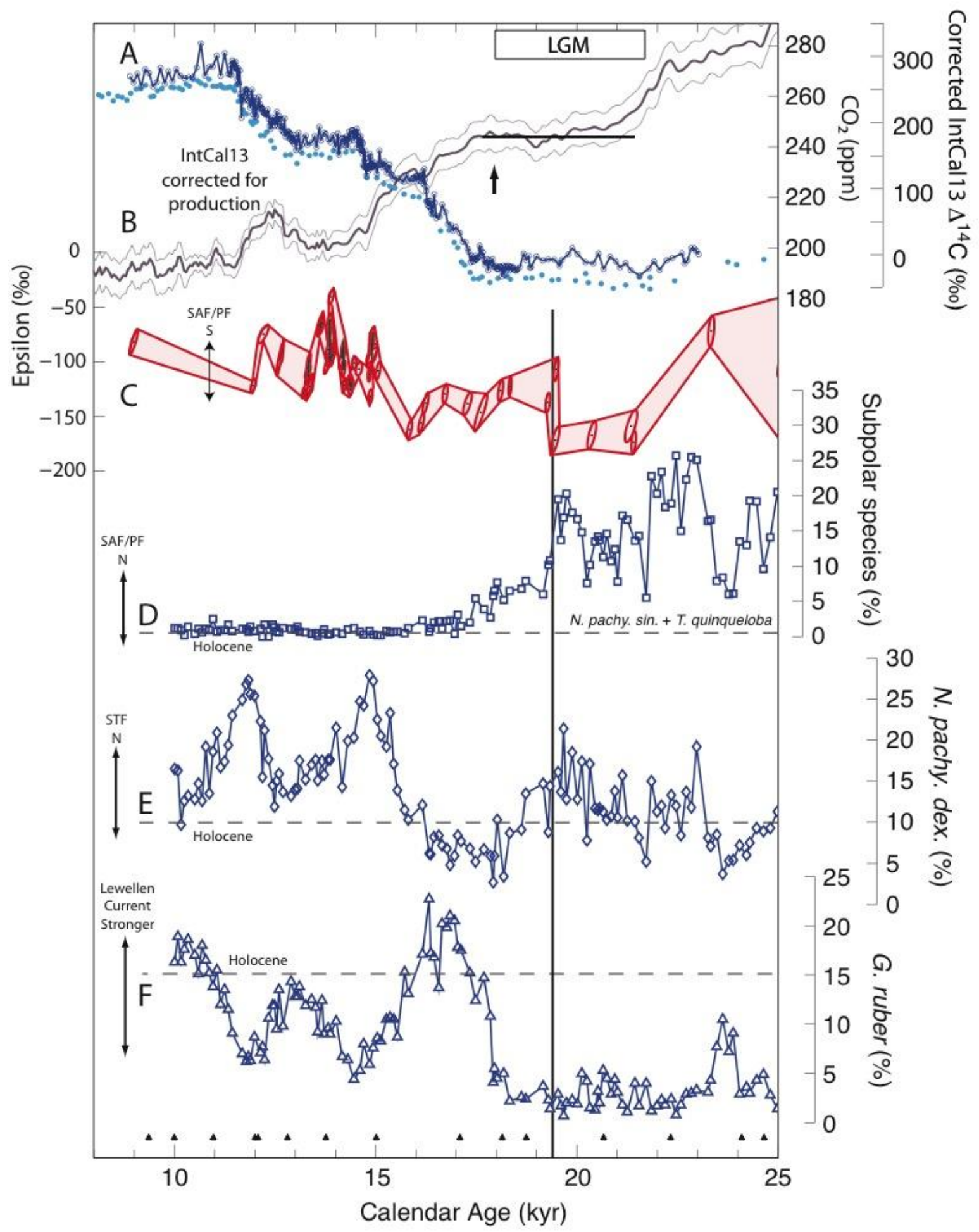

Figure 5. $\Delta^{14} \mathrm{C}$ changes and frontal movement in the Southern Ocean. A) Atmospheric $\mathrm{CO}_{2}$ curves from EPICA Dome C (through $22 \mathrm{ka}$ ) on the timescale of Lemieux-Dudon and Taylor Dome (20 - $25 \mathrm{ka})$ (Indermühle et al., 2000; Lemieux-Dudon et al., 2010; Monnin et al., 2001)(light blue dots) and WAIS (Marcott et al., 2014)(dark blue circles and line) B) The

337 IntCal13 atmospheric $\Delta{ }^{14} \mathrm{C}$ reconstruction corrected for changes in atmospheric ${ }^{14} \mathrm{C}$ production 
(Hain et al., 2014). Arrow at top marks the initiation of $\mathrm{CO}_{2}$ rise at $\sim 18 \mathrm{ka}$. C) The Tasmanian coral $\Delta^{14} \mathrm{C}$ record, converted into epsilon. D-F) Foraminiferal species assemblages from core MD03-2611 (36 43.8' S, 136 32.9' E; 2420 m) located south of Australia (De Deckker et al., 2012). D) Percent abundance of subpolar foraminiferal species assemblage (N. pachyderma sinestral and T. quinqueloba), indicative of SAF/PF movement. E) N. pacyderma dextral percent abundance, indicative of STF movement. F) G. ruber percent abundance, representative of the strength of the Lewellen Current. Black triangles at the bottom of the figure are age control points for MD03-2611 based on calibrated ${ }^{14} \mathrm{C}$ ages.

Although this initial pulse of meltwater at $\sim 19$ ka prompts a shift in Tasmanian

347 intermediate water $\Delta^{14} \mathrm{C}$, the bulk of the carbon system stays in steady state through this interval,

348 as indicated by the production-corrected IntCal13 record and atmospheric $\mathrm{CO}_{2}$. The deep ocean

349 exerts the strongest influence on the $\Delta{ }^{14} \mathrm{C}$ value of the atmosphere and $\mathrm{CO}_{2}$ because it is old and

350 contains a large volume of regenerated $\mathrm{CO}_{2}$. The disconnect between intermediate water $\Delta^{14} \mathrm{C}$

351 and atmospheric $\Delta{ }^{14} \mathrm{C}$ at $\sim 19$ ka indicates that deep and intermediate waters are not acting

352 together and the upper and lower circulation cells are separate.

353 Early in the deglaciation atmospheric $\mathrm{CO}_{2}$ begins to rise as recorded in the Epica Dome $\mathrm{C}$

354 and WAIS divide ice cores (at $\sim 17.5 \mathrm{ka}$ according to EDC and $\sim 18 \mathrm{ka}$ according to

355 WAIS)(Figure 5a)(Lemieux-Dudon et al., 2010; Marcott et al., 2014; Monnin et al., 2001).

356 Despite this big change in the ocean-atmosphere carbon system, there is very little change in

357 intermediate water $\Delta{ }^{14} \mathrm{C}$. The insensitivity of intermediate water $\Delta{ }^{14} \mathrm{C}$ to early changes in

358 atmospheric $\mathrm{CO}_{2}$ indicates, again, that intermediate water is behaving independently from deep

359 water. A comparison of epsilon values from Tasmania to other deglacial radiocarbon records

360 from the Chilean Margin, Drake Passage, deep South Atlantic, and the Chatham Rise, shows this

361 general pattern, with the deepest water getting younger most dramatically at the start of HS1 and

362 shallower water not changing (Figure 6c, Supplemental figure 2) (Burke and Robinson, 2012; De

363 Pol-Holz et al., 2010; Skinner et al., 2015; 2010). 


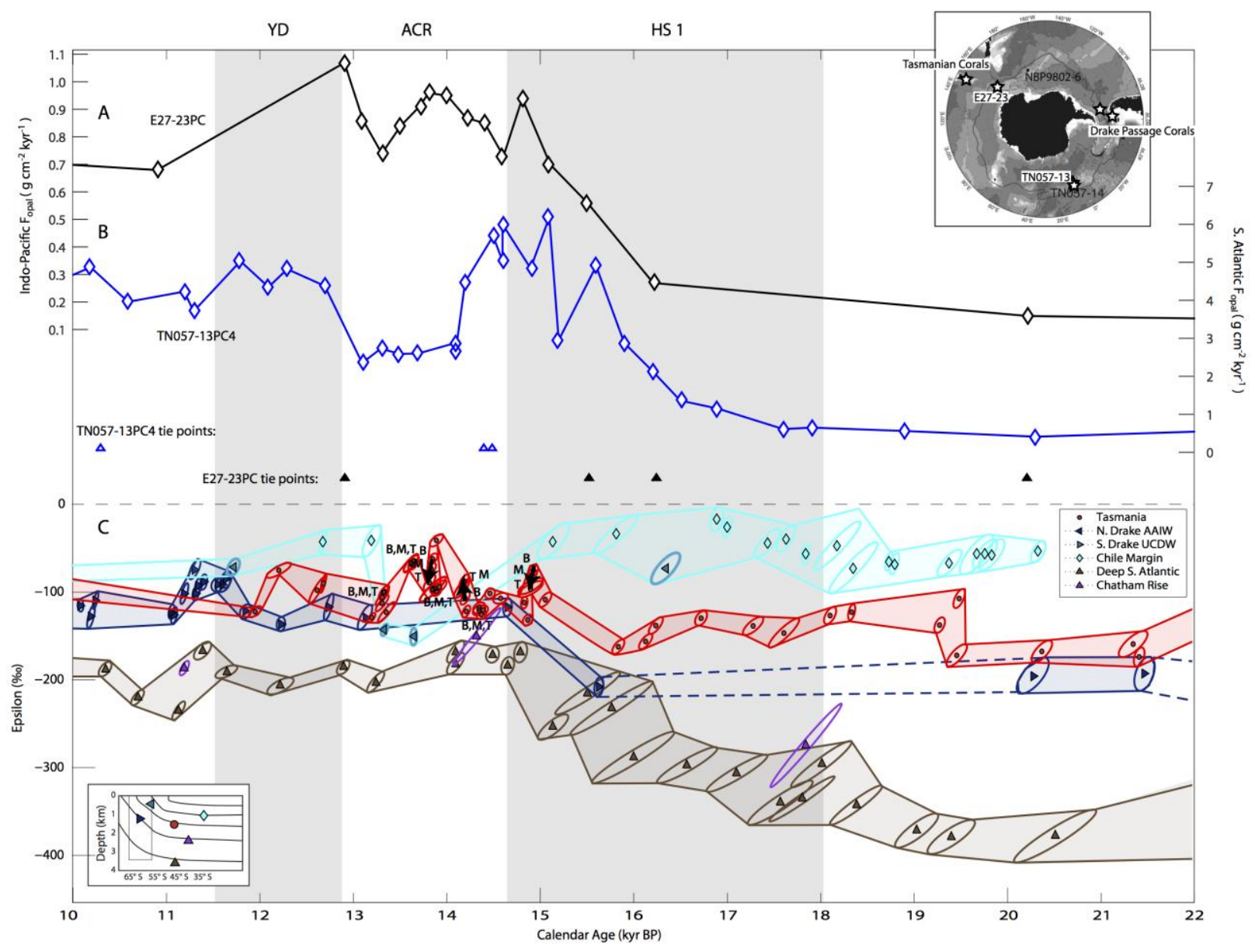

364
Figure 6. Opal flux and epsilon radiocarbon records from the Southern Ocean across the deglaciation. A) Opal flux record from Indo-Pacific core E27-23 $\left(59.62^{\circ} \mathrm{S} 155.24^{\circ} \mathrm{E}, 3182 \mathrm{~m}\right)$. B) Opal flux record from South Atlantic core TN057-13 (53.1728 $\left.{ }^{\circ} \mathrm{S} 5.1275^{\circ} \mathrm{E}, 2848 \mathrm{~m}\right)$. Error bars on opal flux values are the size of the points. Also included are chronological constraints (from calibrated ${ }^{14} \mathrm{C}$ dates) for both cores, with E27-23 tie points in filled black triangles and TN057-13 tie points in open blue triangles. C) Tasmanian coral $\Delta^{14} \mathrm{C}$ record shown as epsilon units offset from the atmosphere with other Southern Ocean records $\Delta^{14} \mathrm{C}$ records. Deep South Atlantic (Skinner et al., 2010) (brown ellipses and upward-facing triangles; core MD07-3076; 44.1 ${ }^{\circ} \mathrm{S}$ $14.2^{\circ} \mathrm{E}, 4981 \mathrm{~m}$ ), southern Drake Passage UCDW (Burke and Robinson, 2012) (dark blue ellipses and right-facing triangles; $\sim 60^{\circ} \mathrm{S}, \sim 1000 \mathrm{~m}$ ), northern Drake passage AAIW (Burke and Robinson, 2012) (dark teal ellipses and left-facing triangles; $\sim 55^{\circ} \mathrm{S}, 500 \mathrm{~m}$ ), Chilean Margin (De Pol-Holz et al., 2010) (teal ellipses and diamonds; core SO161-SL22; $36.2^{\circ} \mathrm{S} 73.7^{\circ} \mathrm{W}, 1000 \mathrm{~m}$ ), Chatham Rise (Skinner et al., 2015) (purple ellipses and upward-facing triangles; core MD97$2121 ; 40.4^{\circ} \mathrm{S} 178.0^{\circ} \mathrm{E}, 2314 \mathrm{~m}$ ), and Tasmania (this study) (red ellipses and circles; $\sim 45^{\circ} \mathrm{S}$, $\sim 1600 \mathrm{~m})$. "T, M, B" labels refer to top, middle, and bottom $\Delta{ }^{14} \mathrm{C}$ values for individual corals. Of corals with top, middle, and bottom dates, only three show resolvable changes over the coral's lifespan (see Figure 3). The direction of these changes is marked with an arrow. Top right: map showing the locations of cores TN057-13 and E27-23, Drake Passage Corals and Tasmanian 
383 corals. Bottom left: schematic showing modern Southern Ocean zonally-averaged isopycnal

384 structure, Drake Passage location, and locations of epsilon records (in color-coded symbols).

$385 \quad 4.2$ RAPID VARIABILITY AND ZONAL ASYMMETRY DURING THE ACR

386 In the Tasmanian coral $\Delta{ }^{14} \mathrm{C}$ record, the ACR stands out compared to the rest of the

387 deglaciation due to its large and abrupt changes in $\Delta{ }^{14} \mathrm{C}$, and unprecedented resolution (Figure

388 6c). Average sample resolution during the ACR $(14.7-12.9 \mathrm{ka})$ is 55 years, including 6 corals

389 that have been sub-sampled (excluding the 6 sub-sampled corals decreases the average sample

390 resolution to 105 years, which is still high compared to most marine records). The variability

391 during this time period is not only seen between corals but also within the lifetimes of several

392 individuals (Figure 3 and Figure 6c). Because of the inherent stratigraphy of each skeleton, top

393 middle and bottom dates are able to resolve changes in intermediate water radiocarbon that

394 would otherwise be within calendar age measurement error. The largest of these jumps occurs at

$39513.9 \mathrm{ka}$ and has a magnitude of $30 \%$ over approximately 35 years. The standard deviation of

396 detrended inter-sample epsilon values during the ACR (i.e. excluding middle and bottom

397 samples) is twice as large as during the LGM and HS1, and a Levene's Test (Levene, 1960)

398 comparing the detrended inter-sample epsilon variability during the ACR to that of the

$399 \mathrm{LGM} / \mathrm{HS} 1$ rejects the null hypothesis that the variances are equal at the $82 \%$ confidence level (p

$400=0.177)$. It cannot completely be ruled out however, that this difference is the result of the three-

401 fold higher sampling resolution during the ACR compared to the LGM/HS1.

402 The rapidity of these radiocarbon fluctuations implicates frontal shifts, rather than

403 changes in circulation strength, either at the surface or at depth. In the modern ocean south of

404 Tasmania, a $30 \%$ shift in $\Delta{ }^{14} \mathrm{C}$ would require fronts to move $\sim 10^{\circ}$ latitude based on the surface

405 meridional $\Delta{ }^{14} \mathrm{C}$ gradient of $\sim 3 \%$ per degree (Figure 1). However, some of the inter-sample $\Delta{ }^{14} \mathrm{C}$

406 shifts during this time are as large as $80 \%$, which would require a frontal shift of over $25^{\circ}$ 
407 latitude based on this same gradient. Given that the Southern Ocean is only about $20^{\circ}$ of latitude

408 wide south of Tasmania, it is clearly unreasonable to assume that the surface $\Delta^{14} \mathrm{C}$ gradient was

409 the same during the ACR. It seems very likely that frontal gradients would have been enhanced

410 during this time because older deep water upwelling around the Antarctic continent would

411 reduce $\Delta{ }^{14} \mathrm{C}$ values to the south thereby increasing the total gradient across the Southern Ocean.

412 This would decrease the magnitude of SAF/PF shift required to fit our data.

413 Frontal shifts of $5-10^{\circ}$ over the deglaciation have been previously suggested for the

414 Southern Ocean by several different studies (Kohfeld et al., 2013; Sikes et al., 2009). In the most

415 comprehensive frontal reconstructions, shifts of $4-5^{\circ}$ have been suggested for the SAF and PF

416 and shifts of $3-5^{\circ}$ have been suggested for the Subtropical Front (STF) (Kohfeld et al., 2013).

417 Differences between the exact location and the temporal resolution of these frontal

418 reconstructions compared to our record makes comparisons of the timing of these frontal shifts

419 less informative than the magnitude of change. There are high-resolution data from south of

420 Australia (De Deckker et al., 2012) through this time period, but the foram abundances indicate

421 that subtropical waters are primarily influencing the core region. Our Tasmanian intermediate

422 water corals are not especially sensitive to Subtropical Front position (NPD percent abundance)

423 or Lewellen Current intensity (G. ruber percent abundance), so we do not expect these foram

424 records to be directly comparable to our $\Delta{ }^{14} \mathrm{C}$ record during this time period.

425 Shifts in the position of Southern Ocean fronts, driven by the position of the westerly

426 winds are thought to influence the rate of Southern Ocean upwelling and $\mathrm{CO}_{2}$ degassing

427 (Anderson et al., 2009; Toggweiler et al., 2006). This is exemplified in the opal flux record from

428 core TN057-13 $\left(53.1728^{\circ} \mathrm{S} 5.1275^{\circ} \mathrm{E}, 2848 \mathrm{~m}\right)$ in the South Atlantic (Anderson et al., 2009). This

429 record shows low opal fluxes during the LGM, consistent with Southern Ocean westerly winds 
430 shifted north, outside of the Drake Passage latitude band (Anderson et al., 2009; Toggweiler et

431 al., 2006). At the start of HS1, Northern Hemisphere cooling shifts the westerlies to the south,

432 prompting increased upwelling and higher opal fluxes. This process is reversed at the Bølling-

433 Allerød/ACR, where the Northern Hemisphere warms, and then reversed again at the Younger

434 Dryas, causing a pattern of reduced then increased opal flux (Anderson et al., 2009). Other

435 Southern Ocean records from near this core location highlight the ACR as a time of surface

436 stratification and reduced upwelling (Anderson et al., 2009; Burke and Robinson, 2012; Siani et

437 al., 2013).

438 During the end of HS1, leading up to the ACR, there seems to be a coherent Southern

439 Ocean response. Upwelling leading to increased opal flux in the South Atlantic (Anderson et al., 4402009 ) and increases in UCDW epsilon values seen in the Drake Passage (Burke and Robinson,

441 2012) are mirrored by increased opal flux in Indo-Pacific sector core E27-23 (Anderson et al.,

442 2009) (Figure $6 \mathrm{a} ; 59.62^{\circ} \mathrm{S} 155.24^{\circ} \mathrm{E}, 3182 \mathrm{~m}$ ) and increases in epsilon south of Tasmania.

443 However, the classic Southern hemisphere pattern of reduced upwelling and enhanced

444 stratification during the middle of the ACR, typified by the South Atlantic opal flux record, is

445 distinctly different from the pattern seen in the Indo-Pacific sector core (Figure 6b). In E27-23

446 there is upwelling throughout the ACR with some amount of temporal variability. It is tempting

447 to look for a correlation between the Indo-Pacific opal flux record, as an indicator of front

448 position, and the rapid, short-timescale variability in the Tasmanian coral epsilon record. Indeed

449 the Indo-Pacific opal flux and Tasmanian coral epsilon records do seem to line up, however the 450 age model for Indo-Pacific core E27-23 is much less well constrained than that of South Atlantic 451 core TN057-13. There are three calendar age tie points for E27-23 between $12-17 \mathrm{ka}$, so if the 452 opal flux data from E27-23 were shifted to better match the patterns in TN057-13, it would 
453 require two abrupt changes in sedimentation rate during this time period. The observation that

454 Indo-Pacific opal fluxes do not look the same as South Atlantic opal fluxes, and their close

455 correspondence with the Tasmanian coral $\Delta{ }^{14} \mathrm{C}$, indicates that there is zonal asymmertry across

456 the Southern Ocean during the ACR.

457 Although the Drake Passage UCDW record looks quite similar to our Tasmanian coral

458 record during the end of HS1, a comparison of Tasmanian coral epsilon values to both the

459 UCDW and AAIW records from Drake Passage during this time shows potential differences

460 (Figure 6c). This is most obvious at $\sim 13.6 \mathrm{ka}$, where one Drake Passage AAIW sample falls

461 almost 100\%o below the contemporaneous Tasmanian coral samples. The Drake Passage corals

462 more closely resemble the South Atlantic opal flux record, while the Tasmanian corals more

463 closely resemble the Indo-Pacific opal flux record (Figure 6), despite the fact that the Tasmanian

464 record should fall between the two Drake Passage records according to a zonally symmetric view

465 of the modern hydrography (Figure 6, inset at lower left). Drake Passage is unique in the

466 Southern Ocean, as it steers all the volume of the ACC and many of the Southern Ocean fronts

467 through a fairly narrow channel, so one might expect fronts to behave differently in this region

468 than they would south of Tasmania. Although there are some important topographic features

469 south of Tasmania, such as the Tasman Plateau, this primarily influences the position of the

470 Subtropical Front, leaving the Subantarctic and Polar Fronts free to move. It is also important to

471 note that the discrepancy between the Drake Passage and Tasmanian coral records is largely

472 driven by a gap in the UCDW record between $14.7-13.1 \mathrm{ka}$, so it is also possible that apparent

473 zonal differences are simply driven by a lack of temporal overlap between the records. For the

474 foraminiferal records (De Pol-Holz et al., 2010; Skinner et al., 2015; 2010), fronts near the Chile

475 Margin and Chatham Rise should be less affected by topography than those in the Southeast 
476 Atlantic, however sampling gaps make it impossible to determine the extent to which frontal

477 movement influences $\Delta{ }^{14} \mathrm{C}$ values at these locations.

\subsection{INTERMEDIATE WATER PERSPECTIVES ON DEGLACIAL OVERTURNING} CIRCULATION

One of the strongest climate signals through the deglaciation is the rise in atmospheric

$481 \mathrm{CO}_{2}$ and its connection with Southern Hemisphere warming and deep ocean ventilation (Figure

482 7c, d, f) (Marcott et al., 2014; Skinner et al., 2010; WAIS Divide Project Members, 2013). On

483 top of this broad signal there are abrupt $\sim 12 \mathrm{ppm}$ rises in $\mathrm{pCO}_{2}$ at $\sim 16 \mathrm{ka}$ and $\sim 14.7 \mathrm{ka}$ (Marcott

484 et al., 2014). This first abrupt $\mathrm{CO}_{2}$ increase occurs at about the same time as Heinrich Event 1

485 and the associated maximum weak monsoon interval seen in the Hulu cave record (Figure 7b)

486 (Wang et al., 2001). This interval is thought to be associated with a southward shift of the ITCZ

487 and other atmospheric wind systems (McGee et al., 2014), which should show up in Tasmanian

488 intermediate water $\Delta{ }^{14} \mathrm{C}$ as a positive shift in epsilon values. Instead intermediate water $\Delta^{14} \mathrm{C}$

489 gets gradually older.

490 This somewhat surprising observation could be the result of mechanism 2 in Figure 1c-

491 at this time there is convergence between deeper and shallower water masses (Figure 7f) (Burke

492 and Robinson, 2012), indicating that the deep overturning cells have become temporarily more

493 interconnected. After this convergence, there is a pause in atmospheric $\mathrm{CO}_{2}$ rise, indicating less

494 ventilation of deep water, perhaps due to expanded sea ice, which shoals the boundary between

495 the upper and lower cells and reduces mixing between intermediate and deep waters. Without the

496 influence of old deep water, Tasmanian intermediate water $\Delta{ }^{14} \mathrm{C}$ returns to the value dictated by

497 the position of the fronts in the Southern Ocean (Figure 7e). At $\sim 15 \mathrm{ka}$, the ITCZ starts to move 498 north and intermediate water epsilon values drop. 
At the start of the Bølling, there is another 12 ppm increase in atmospheric $\mathrm{CO}_{2}$. This

500 could be the result of deep convection in the North Atlantic, possibly associated with

501 thermobaric capacitance and stored heat at mid-depths (Thiagarajan et al., 2014). There is also a

502 slight convergence of intermediate and deeper waters in the Southern Ocean at this time, so

503 perhaps there is also a southern source to this atmospheric $\mathrm{CO}_{2}$ rise. During the rest of the ACR

504 and Bølling-Allerød, atmospheric $\mathrm{CO}_{2}$ stays constant and Antarctic $\delta^{18} \mathrm{O}$ drops (Figure $7 \mathrm{c}, \mathrm{d}, \mathrm{f}$ ).

505 Intermediate water $\Delta^{14} \mathrm{C}$, on the other hand, is highly variable and generally younger than earlier

506 in the deglaciation. As indicated by the constant $\mathrm{pCO}_{2}$, there is separation between the upper and

507 lower circulation cells, while intermediate waters respond to atmospheric forcing unbuffered by

508 mixing of deeper and older waters.

509 If the rapid fluctuations in Tasmanian coral $\Delta{ }^{14} \mathrm{C}$ record during the ACR/Bølling-Allerød

510 are due to frontal movement in the Southern Ocean, then the question of what drives these shifts

511 arises. Antarctic $\delta^{18} \mathrm{O}$ drops during the ACR, but there is no resolvable second-order variability

512 on top of the broader shift in isotope value (Figure 7c). On the other hand, there is structure

513 within the Greenland $\delta^{18} \mathrm{O}$ record during the Bølling-Allerød (Figure 7a). During the early part

514 of the ACR/Bølling, there is some correspondence between Greenland $\delta^{18} \mathrm{O}$ and Tasmanian coral

$515 \Delta \Delta^{14} \mathrm{C}$, as illustrated by vertical dashed lines in Figure 7. By the same mechanism previously

516 discussed to explain the frontal shift at $19 \mathrm{ka}$, a sharp drop in Greenland $\delta^{18} \mathrm{O}$ should shift winds

517 and fronts to the south and lead to an increase in Tasmanian coral epsilon. While this

518 correspondence between Tasmanian coral epsilon and Greenland $\delta^{18} \mathrm{O}$ holds for the first two

519 sharp drops (at 14.1 and $13.6 \mathrm{ka}$ ), by about $13.3 \mathrm{ka}$ Southern Ocean intermediate water records

520 have converged again and there is no longer a connection between Tasmanian corals and

521 Greenland, though there is a slight gap in the coral record at this time. 


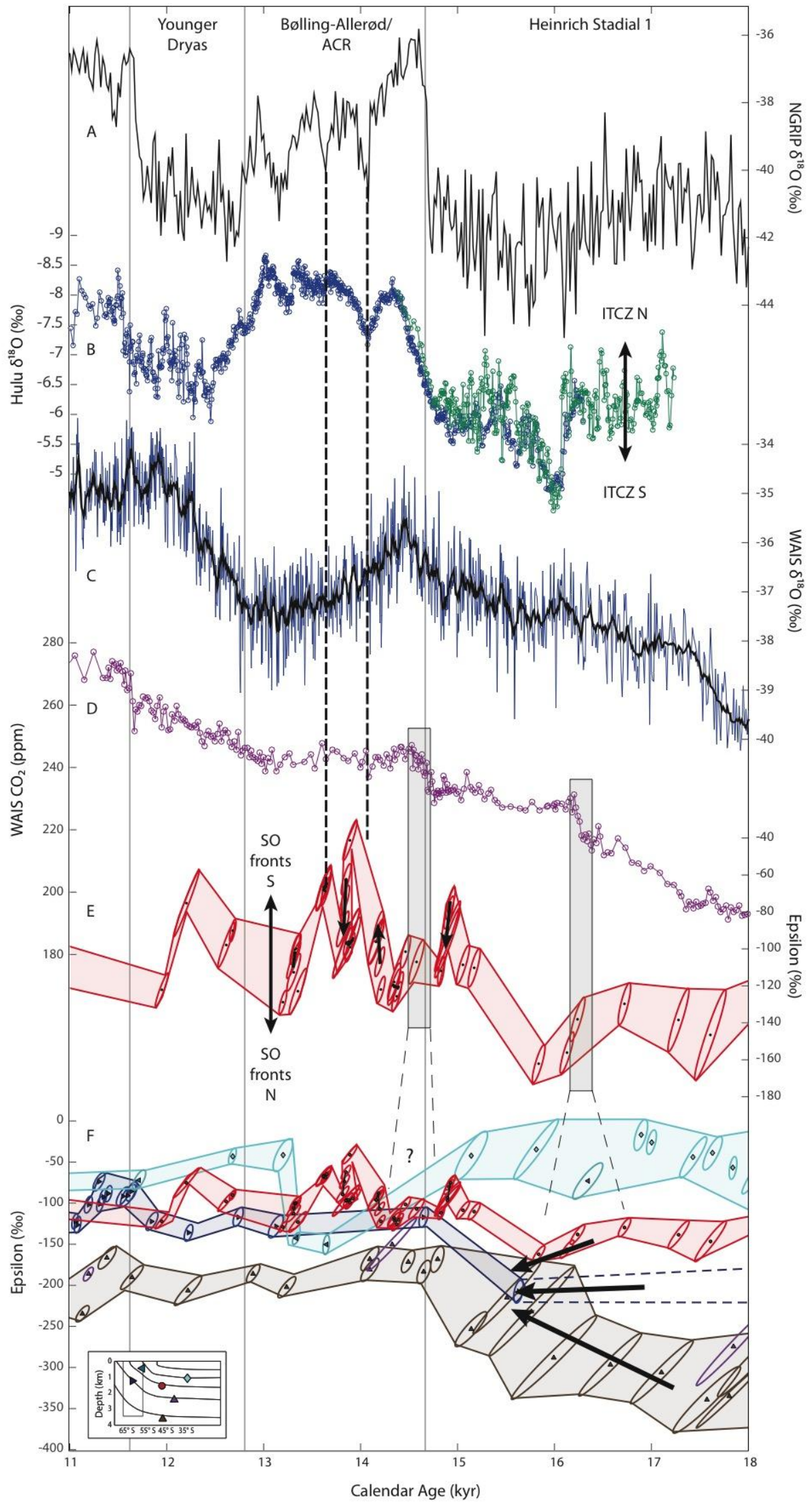


523 Figure 7. Records of the full deglacial period showing changes in overturning circulation. A)

524 NGRIP $\delta^{18} \mathrm{O}$ from Greenland (Andersen et al., 2006; Rasmussen et al., 2006). B) Hulu cave $\delta^{18} \mathrm{O}$

525 from stalagmites H82 (blue) and YT (green) (Wang et al., 2001). C) WAIS Divide $\delta^{18} \mathrm{O}$ from

526 west Antarctica (WAIS Divide Project Members, 2013). D) Atmospheric $\mathrm{CO}_{2}$ from WAIS

527 Divide (Marcott et al., 2014). E) $\Delta{ }^{14} \mathrm{C}$ record from south of Tasmania represented as epsilon (this

528 study). F) Tasmanian $\Delta{ }^{14} \mathrm{C}$ record with other Southern Ocean $\Delta{ }^{14} \mathrm{C}$ records (same colors and

529 symbols as Figure 6c)(Burke and Robinson, 2012; De Pol-Holz et al., 2010; Skinner et al., 2015;

530 2010).

\subsection{OTHER TIMES OF INTERMEDIATE WATER VARIABILITY}

The earliest part of the Tasmanian coral $\Delta{ }^{14} \mathrm{C}$ record is also characterized by rapid, albeit

533 more ambiguous, variability. This variability directly contrasts with the LGM section of the

534 record where intermediate water $\Delta{ }^{14} \mathrm{C}$ clearly follows the atmosphere, and indicates that the

535 ocean is most likely not in steady state during this interval $(\sim 28-23 \mathrm{ka})$. The timing of

536 variability and non-steady state behavior seen early in the Tasmanian coral record is not

537 surprising, however, since it follows the transition between Marine Isotope Stages 3 and 2

538 (Lisiecki and Raymo, 2005). Around $25 \mathrm{ka}$ in particular there is a large range of $\Delta^{14} \mathrm{C}$ values.

539 While this spread in $\Delta^{14} \mathrm{C}$ may be driven by the same mechanisms that lead to intermediate water

540 variability later in the record, it is difficult to resolve specific changes in intermediate water

541 radiocarbon due to uncertainty in the radiocarbon dates driven by error associated with deep-sea

542 coral blanks (Supplemental Figure 1). Therefore, it is hard to determine a specific forcing or

543 mechanism for $\Delta{ }^{14} \mathrm{C}$ change. It is worth noting that two of the earliest samples in the record

544 overlap with the IntCal13 atmospheric $\Delta{ }^{14} \mathrm{C}$ record. This is quite unusual due to old surface

545 reservoir ages in the Southern Ocean, however there is a great deal of scatter among the datasets

546 that comprise the IntCal13 atmospheric $\Delta{ }^{14} \mathrm{C}$ compilation during this time period, so the apparent

547 overlap between our record and the atmosphere is not necessarily representative of intermediate

548 water of zero age. 
550 intermediate water $\Delta{ }^{14} \mathrm{C}$ between $27.6-26.2 \mathrm{ka}$. The trajectory of this drop closely matches that

551 of ${ }^{14} \mathrm{C}$ decay, implicating in situ ageing of a water mass. It also closely matches the initial portion

552 of a $\Delta{ }^{14} \mathrm{C}$ drop from the Brazil Margin observed by Mangini et al. starting at $27.9 \mathrm{ka}$

553 (Supplemental Figure 3)(Mangini et al., 2010). Mangini et al. suggest that this drop in

554 intermediate water $\Delta{ }^{14} \mathrm{C}$ is related to a slowdown in the meridional overturning circulation

555 during Heinrich 2. Yet a circulation slowdown that would give decay-like $\Delta{ }^{14} \mathrm{C}$ trajectories

556 implies complete stagnation of the water, or an unlikely mixing scenario between multiple water

557 masses. In addition, deep circulation changes in the North Atlantic and southern sourced

558 intermediate waters are not expected to be in phase if the 'seesaw' mechanism (Broecker, 1998)

559 is still at work during this time. Another possible mechanism is mixing with ${ }^{14} \mathrm{C}$-dead water.

560 While it would be difficult to simulate a decay-like $\Delta^{14} \mathrm{C}$ trajectory by mixing water masses that

561 contain radiocarbon, a 50:50 mixture with ${ }^{14} \mathrm{C}$-dead water over 5730 years naturally mimics

562 decay. If mixing with ${ }^{14} \mathrm{C}$-dead water was the cause of the decay-like drop in $\Delta^{14} \mathrm{C}$ at $\sim 27.6 \mathrm{ka}$,

563 however, the source of this water remains elusive.

564 The $250 \%$ o $\Delta{ }^{14} \mathrm{C}$ drop at $27.6 \mathrm{ka}$ is similar in magnitude to some of the intermediate water 565 variability observed during the ACR. However, the high-resolution data during the deglaciation

566 clearly distinguish the intermediate water changes from the stagnation signature of ${ }^{14} \mathrm{C}$ decay. It

567 is therefore not hard to imagine that higher-resolution data at $27.6 \mathrm{ka}$ might also differentiate this

568 three-point $\Delta{ }^{14} \mathrm{C}$ drop from a decay trajectory. Likewise, more data could potentially change the

569 interpretation of the Brazil Margin record, however, the longer duration of each stagnation event

570 and repetition of decay trajectories over their entire interval sets their dataset apart from the

571 alternating variability and steady-state behavior observed in our intermediate water record. 


\section{5. Conclusion}

573 Our high-resolution $\Delta{ }^{14} \mathrm{C}$ record from south of Tasmania highlights times during the

574 deglaciation when the upper and lower cells of the MOC are more or less interconnected. It also

575 emphasizes the importance of fronts in the Southern Ocean for determining the radiocarbon

576 values and short-term variability of intermediate waters.

577 During much of the Last Glacial Maximum we see evidence for steady state circulation.

578 Tasmanian intermediate water $\Delta{ }^{14} \mathrm{C}$ follows the contemporaneous atmosphere, and production-

579 corrected atmospheric $\Delta{ }^{14} \mathrm{C}$ is nearly constant in time. There is however one obvious departure

580 from steady-state at around $19 \mathrm{ka}$, where a 10-15 m sea level rise (Yokoyama et al., 2000) is

581 accompanied by a southward shift of the Subantarctic and Polar Fronts (De Deckker et al., 2012)

582 and a $40 \%$ rise in intermediate water $\Delta^{14} \mathrm{C}$. This abrupt shift only impacts the upper cell

583 however-production-corrected atmospheric $\Delta{ }^{14} \mathrm{C}$ values and atmospheric $\mathrm{CO}_{2}$ are unaffected.

584 Intermediate water south of Tasmania is much more dynamic beginning late in HS1 and

585 continuing through the Antarctic Cold Reversal. Fronts are aligned with the large-scale density

586 structure of the Southern Ocean, and because of the pattern of upwelling, these fronts are also

587 aligned with radiocarbon gradients. Frontal position is strongly influenced by topography

588 (Graham et al., 2012), but in the absence of large topographic features, fronts are free to move in

589 response to Southern Ocean westerly winds (Sallée et al., 2008). Although on a large scale the

590 Southern Ocean is zonally symmetric there is important regional variability, largely driven by

591 topography. This zonal asymmetry helps explain why Tasmanian intermediate water $\Delta^{14} \mathrm{C}$ and

592 Indo-Pacific upwelling records deviate from similar South Atlantic records (Anderson et al.,

593 2009; Burke and Robinson, 2012; De Pol-Holz et al., 2010; Skinner et al., 2015; 2010). 
594 Tasmanian intermediate water $\Delta^{14} \mathrm{C}$ shows that the classic view of weakened overturning 595 in the Southern Ocean during the Antarctic Cold Reversal is not appropriate for all regions. The

596 timing of intermediate water $\Delta^{14} \mathrm{C}$ variability south of Tasmania during parts of the ACR

597 matches with $\delta^{18} \mathrm{O}$ values measured in Greenland ice and Chinese speleothems. This upper cell

598 variability and connection to Northern Hemisphere records indicates a separation between the

599 circulation cells and less of a deep water influence at the sample location during this time. Earlier

600 in the deglaciation, at $\sim 16 \mathrm{ka}$, atmospheric signals associated with Heinrich Event 1 are not

601 immediately seen in Tasmanian intermediate waters because they are overprinted by the effects

602 of mixing with old deeper water masses. By the end of the ACR, overturning circulation more

603 closely matches the modern and intermediate and deep water masses are organized accordingly.

604 Early in the record, following the Marine Isotope Stage 3-2 transition at $29 \mathrm{ka}$, there is

605 also a great deal of variability in intermediate water $\Delta{ }^{14} \mathrm{C}$, however it is more difficult to resolve

606 clear patterns and connect them to specific forcings. One discernable feature is a 1400 -year

$607250 \%$ drop starting at $27.6 \mathrm{ka}$, which closely follows the trajectory of ${ }^{14} \mathrm{C}$ decay. This $\Delta^{14} \mathrm{C}$ drop

608 corresponds to the first half of a drop observed off the coast of Brazil (Mangini et al., 2010). We

609 hesitate to interpret our signal as intermediate water stagnation since it is difficult to imagine

610 physical mechanisms wherein this could be achieved. The magnitude of this drop is similar to

611 some of the variability observed during the ACR section of the record. Whereas the high-

612 resolution data during the deglaciation clearly distinguish intermediate water $\Delta^{14} \mathrm{C}$ variability

613 from ${ }^{14} \mathrm{C}$ decay, the lack of data density at 27.6 ka makes this distinction difficult. More $\Delta{ }^{14} \mathrm{C}$

614 measurements could lead to a better understanding of the mechanisms at play during this time

615 period, but we recovered few corals that grew during this time. 


\section{Acknowledgements}

618

619

620

621

622

623

624

625

626

627

628

629

630

631

632

633

634

635

636

637

638

639

640

641

642

643

644

645

646

647

648

649

650

651

652

653

654

655

656

657

658

659

660

661

We would like to thank Heather Stoll, the editor of this paper, and three reviewers for their helpful comments. We would also like to acknowledge analytical help from Guillaume Paris. This work was funded by NSF P2C2 grant OCE-1204211.

\section{References}

Adkins, J.F., Griffin, S., Kashgarian, M., Cheng, H., Druffel, E.R.M., Boyle, E.A., Edwards, R.L., Shen, C.-C., 2002. Radiocarbon Dating of Deep-Sea Corals. Radiocarbon 44, 567-580.

Adkins, J.F., Henderson, G.M., Wang, S.L., O'Shea, S., Mokadem, F., 2004. Growth rates of the deep-sea scleractinia Desmophyllum cristagalli and Enallopsammia rostrata. Earth and Planetary Science Letters 227, 481-490. doi:10.1016/j.epsl.2004.08.022

Andersen, K.K., Svensson, A., Johnsen, S.J., Rasmussen, S.O., Bigler, M., Rothlisberger, R., Ruth, U., Siggaard-Andersen, M.-L., Peder Steffensen, J., Dahl-Jensen, D., 2006. The Greenland ice core chronology 2005, 15-42ka. Part 1: constructing the time scale.

Quaternary Science Reviews 25, 3246-3257. doi:10.1016/j.quascirev.2006.08.002

Anderson, R.F., Ali, S., Bradtmiller, L.I., Nielsen, S.H.H., Fleisher, M.Q., Anderson, B.E., Burckle, L.H., 2009. Wind-Driven Upwelling in the Southern Ocean and the Deglacial Rise in Atmospheric CO2. Science 323, 1443-1448. doi:10.1126/science.1167441

Broecker, W.S., 1998. Paleocean circulation during the last deglaciation: A bipolar seesaw? Paleoceanography 13, 119-121.

Burke, A., Robinson, L.F., 2012. The Southern Ocean's Role in Carbon Exchange During the Last Deglaciation. Science 335, 557-561. doi:10.1126/science.1208163

Burke, A., Robinson, L.F., McNichol, A.P., Jenkins, W.J., Scanlon, K.M., Gerlach, D.S., 2010. Reconnaissance dating: A new radiocarbon method applied to assessing the temporal distribution of Southern Ocean deep-sea corals. Deep-Sea Res Pt I 57, 1510-1520. doi:10.1016/j.dsr.2010.07.010

Bush, S.L., Santos, G.M., Xu, X., Southon, J.R., Thiagarajan, N., Hines, S.K., Adkins, J.F., 2013. Simple, rapid, and cost effective: a screening method for $^{\wedge}(14) \mathrm{C}$ analysis of small carbonate samples. Radiocarbon 55, 631-640. doi:10.2458/azu_js_rc.55.16192

Ceppi, P., Hwang, Y.T., Liu, X., Frierson, D.M.W., Hartmann, D.L., 2013. The relationship between the ITCZ and the Southern Hemispheric eddy- driven jet. Journal of Geophysical Research: Atmospheres 118, 1-11.

Cheng, H., Adkins, J., Edwards, R.L., Boyle, E.A., 2000. U-Th dating of deep-sea corals. Geochimica et Cosmochimica Acta 64, 2401-2416.

Clark, P.U., Dyke, A.S., Shakun, J.D., Carlson, A.E., Clark, J., Wohlfarth, B., Mitrovica, J.X., Hostetler, S.W., McCabe, A.M., 2009. The Last Glacial Maximum. Science 325, 710-714. doi:10.1126/science.1172873

Curry, W.B., Oppo, D.W., 2005. Glacial water mass geometry and the distribution of $\delta 13 \mathrm{C}$ of $\Sigma \mathrm{CO} 2$ in the western Atlantic Ocean - Curry - 2005 - Paleoceanography - Wiley Online Library. Paleoceanography.

De Deckker, P., Moros, M., Perner, K., Jansen, E., 2012. Influence of the tropics and southern westerlies on glacial interhemispheric asymmetry. Nature Geoscience 5, 266-269. doi:10.1038/ngeo1431

De Pol-Holz, R., Keigwin, L., Southon, J., Hebbeln, D., Mohtadi, M., 2010. No signature of abyssal carbon in intermediate waters off Chile during deglaciation. Nature Geoscience 3, 
Eltgroth, S.F., Adkins, J.F., Robinson, L.F., Southon, J., Kashgarian, M., 2006. A deep-sea coral record of North Atlantic radiocarbon through the Younger Dryas: Evidence for intermediate water/deepwater reorganization. Paleoceanography 21. doi:10.1029/2005PA001192

Ferrari, R., Jansen, M.F., Adkins, J.F., Burke, A., Stewart, A.L., Thompson, A.F., 2014. Antarctic sea ice control on ocean circulation in present and glacial climates. PNAS 111, 8753-8758. doi:10.1073/pnas.1323922111

Graham, R.M., De Boer, A.M., Heywood, K.J., Chapman, M.R., Stevens, D.P., 2012. Southern Ocean fronts: Controlled by wind or topography? Journal of Geophysical Research: Atmospheres 117. doi:10.1029/2012JC007887

Hain, M.P., Sigman, D.M., Haug, G.H., 2014. Earth and Planetary Science Letters. Earth and Planetary Science Letters 394, 198-208. doi:10.1016/j.epsl.2014.03.020

Indermühle, A., Monnin, E., Stauffer, B., Stocker, T.F., Wahlen, M., 2000. Atmospheric CO2 concentration from 60 to $20 \mathrm{kyr}$ BP from the Taylor Dome Ice Core, Antarctica. Geophysical Research Letters 27, 735-738. doi:10.1029/1999GL010960

Kang, S.M., Held, I.M., Frierson, D.M.W., Zhao, M., 2008. The Response of the ITCZ to Extratropical Thermal Forcing: Idealized Slab-Ocean Experiments with a GCM. J. Climate 21, 3521-3532. doi:10.1175/2007JCLI2146.1

Key, R., Kozyr, A., Sabine, C., Lee, K., Wanninkhof, R., Bullister, J., Feely, R., Millero, F., Mordy, C., Peng, T., 2004. A global ocean carbon climatology: Results from Global Data Analysis Project (GLODAP). Global Biogeochemical Cycles 18, -. doi:10.1029/2004GB002247

Knox, F., McElroy, M.B., 1984. Changes in atmospheric CO2: Influence of the marine biota at high latitude. Journal of Geophysical Research: Atmospheres 89, 4629. doi:10.1029/JD089iD03p04629

Kohfeld, K.E., Graham, R.M., de Boer, A.M., Sime, L.C., Wolff, E.W., Le Quere, C., Bopp, L., 2013. Southern Hemisphere westerly wind changes during the Last Glacial Maximum: paleo-data synthesis. Quaternary Science Reviews 68, 76-95. doi:10.1016/j.quascirev.2013.01.017

Laj, C., Kissel, C., Mazaud, A., Michel, E., 2002. Geomagnetic field intensity, North Atlantic Deep Water circulation and atmospheric $\Delta 14 \mathrm{C}$ during the last 50 kyr. Earth and Planetary ... 200, 177-190.

Lemieux-Dudon, B., Blayo, E., Petit, J.-R., Waelbroeck, C., Svensson, A., Ritz, C., Barnola, J.M., Narcisi, B.M., Parrenin, F., 2010. Quaternary Science Reviews. Quaternary Science Reviews 29, 8-20. doi:10.1016/j.quascirev.2009.11.010

Levene, H., 1960. Robust test for equality of variances, in: Olkin, I., Ghurye, S.G., Hoeffding, W., Madow, W.G., B, M.H. (Eds.), In Contributions to Probability and Statistics: Essays in Honour of Harold Hotelling. Stanford University Press, Stanford, pp. 278-292.

Lisiecki, L.E., Raymo, M.E., 2005. A Pliocene- Pleistocene stack of 57 globally distributed benthic $\delta 18 \mathrm{O}$ records. Paleoceanography 20.

Lund, D.C., Adkins, J.F., Ferrari, R., 2011. Abyssal Atlantic circulation during the Last Glacial Maximum: Constraining the ratio between transport and vertical mixing. Paleoceanography 26. doi:10.1029/2010PA001938

Mangini, A., Godoy, J.M., Godoy, M.L., Kowsmann, R., Santos, G.M., Ruckelshausen, M., Schroeder-Ritzrau, A., Wacker, L., 2010. Deep sea corals off Brazil verify a poorly ventilated Southern Pacific Ocean during H2, H1 and the Younger Dryas. Earth and 
Planetary Science Letters 293, 269-276. doi:10.1016/j.epsl.2010.02.041

710

711

712

713

714

715

716

717

718

719

720

721

722

723

724

725

726

727

728

729

730

731

732

733

734

735

736

737

738

739

740

741

742

743

744

745

746

747

748

749

750

751

752

753

Marcott, S.A., Bauska, T.K., Buizert, C., Steig, E.J., Rosen, J.L., Cuffey, K.M., Fudge, T.J., Severinghaus, J.P., Ahn, J., Kalk, M.L., McConnell, J.R., Sowers, T., Taylor, K.C., White, J.W.C., Brook, E.J., 2014. Centennial-scale changes in the global carbon cycle during the last deglaciation. Nature 514, 616-619.

McGee, D., Donohoe, A., Marshall, J., Ferreira, D., 2014. Changes in ITCZ location and crossequatorial heat transport at the Last Glacial Maximum, Heinrich Stadial 1, and the midHolocene. Earth and Planetary Science Letters 390, 69-79. doi:10.1016/j.epsl.2013.12.043

Monnin, E., Indermühle, A., Dällenbach, A., Flückiger, J., Stauffer, B., Stocker, T.F., Raynaud, D., Barnola, J.-M., 2001. Atmospheric CO2 concentrations over the last glacial termination. Science 291, 112-114. doi:10.1126/science.291.5501.112

Muscheler, R., Beer, J., Wagner, G., Laj, C., 2004. Changes in the carbon cycle during the last deglaciation as indicated by the comparison of $10 \mathrm{Be}$ and $14 \mathrm{C}$ records. Earth and Planetary ... 219, 325-240.

Rasmussen, S.O., Andersen, K.K., Svensson, A.M., Steffensen, J.P., Vinther, B., Clausen, H.B., Siggaard-Andersen, M.-L., Johnsen, S.J., Larsen, L.B., Dahl-Jensen, D., Bigler, M., Rothlisberger, R., Fischer, H., Goto-Azuma, K., Hansson, M., Ruth, U., 2006. A new Greenland ice core chronology for the last glacial termination. Journal of Geophysical Research: Atmospheres 111.

Reimer, P.J., Baillie, M.G.L., Bard, E., Bayliss, A., Beck, J.W., Blackwell, P.G., Ramsey, C.B., Buck, C.E., Burr, G.S., Edwards, R.L., Friedrich, M., Grootes, P.M., Guilderson, T.P., Hajdas, I., Heaton, T.J., Hogg, A.G., Hughen, K.A., Kaiser, K.F., Kromer, B., McCormac, F.G., Manning, S.W., Reimer, R.W., Richards, D.A., Southon, J.R., Talamo, S., Turney, C.S.M., van der Plicht, J., Weyhenmeyer, C.E., 2009. IntCal09 and Marine09 radiocarbon age calibration curves, 0-50,000 years cal BP. Radiocarbon 51.

Robinson, L.F., Adkins, J.F., Scheirer, D.S., Fernandez, D.P., Gagnon, A.C., Waller, R.G., 2007. Deep-sea scleractinian coral age and depth distributions in the WN Atlantic for the last 225 thousand years. Bulletin of Marine Science 81, 371-391.

Rose, K.A., Sikes, E.L., Guilderson, T.P., Shane, P., Hill, T.M., Zahn, R., Spero, H.J., 2010. Upper-ocean-to-atmosphere radiocarbon offsets imply fast deglacial carbon dioxide release. Nature 466, 1093-1097. doi:10.1038/nature09288

Sallée, J.B., Speer, K., Morrow, R., 2008. Response of the Antarctic Circumpolar Current to atmospheric variability. J. Climate 21, 3020-3039. doi:10.1175/2007JCLI1702.1

Santos, G.M., Mazon, M., Southon, J.R., Rifai, S., Moore, R., 2007. Evaluation of iron and cobalt powders as catalysts for 14C-AMS target preparation. Nuclear Instruments and Methods in Physics Research Section B: Beam Interactions with Materials and Atoms 259, 308-315. doi:10.1016/j.nimb.2007.01.220

Sarmiento, J.L., Toggweiler, J.R., 1984. A new model for the role of the oceans in determining atmospheric pCO2. Nature 308, 621-624.

Shakun, J.D., Clark, P.U., He, F., Marcott, S.A., Mix, A.C., Liu, Z., Otto-Bliesner, B., Schmittner, A., Bard, E., 2012. Global warming preceded by increasing carbon dioxide concentrations during the last deglaciation. Nature 484, 49-54. doi:doi:10.1038/nature10915

Shen, G.T., Boyle, E.A., 1988. Determination of lead, cadmium and other trace metals in annually-banded corals. Chemical Geology 67, 47-62. doi:10.1016/0009-2541(88)90005-8

Siani, G., Michel, E., De Pol-Holz, R., DeVries, T., Lamy, F., Carel, M.E.L., Isguder, G., Dewilde, F., Lourantou, A., 2013. Carbon isotope records reveal precise timing of enhanced 
Southern Ocean upwelling during the last deglaciation. Nature Communications 4, 1-9. doi: $10.1038 /$ ncomms 3758

Siegenthaler, U., Wenk, T., 1984. Rapid atmospheric CO2 variations and ocean circulation. Nature 308, 624-626. doi:10.1038/308624a0

Sigman, D.M., Hain, M.P., Haug, G.H., 2010. The polar ocean and glacial cycles in atmospheric CO2 concentration. Nature 466, 47-55. doi:10.1038/nature09149

Sikes, E.L., Howard, W.R., Samson, C.R., Mahan, T.S., Robertson, L.G., Volkman, J.K., 2009. Southern Ocean seasonal temperature and Subtropical Front movement on the South Tasman Rise in the late Quaternary. Paleoceanography 24, n/a-n/a. doi:10.1029/2008PA001659

Skinner, L., McCave, I.N., Carter, L., Fallon, S., Scrivner, A.E., Primeau, F., 2015. Reduced ventilation and enhanced magnitude of the deep Pacific carbon pool during the last glacial period. Earth and Planetary Science Letters 411, 45-52. doi:10.1016/j.eps1.2014.11.024

Skinner, L.C., Fallon, S., Waelbroeck, C., Michel, E., Barker, S., 2010. Ventilation of the Deep Southern Ocean and Deglacial CO2 Rise. Science 328, 1147-1151. doi:10.1126/science.1183627

Stuiver, M., Polach, H.A., 1977. Reporting of C-14 Data - Discussion. Radiocarbon 19, 355-363. Talley, L., 2013. Closure of the Global Overturning Circulation Through the Indian, Pacific, and Southern Oceans: Schematics and Transports. Oceanography 26, 80-97. doi: $10.5670 /$ oceanog. 2013.07

Talley, L.D., 2003. Shallow, Intermediate, and Deep Overturning Components of the Global Heat Budget. Journal of Physical Oceanography 33, 530-560.

Thiagarajan, N., Gerlach, D., Roberts, M.L., Burke, A., McNichol, A.P., Jenkins, W.J., Subhas, A., Thresher, R., Adkins, J., 2013. Movement of deep-sea coral populations on climatic timescales. Paleoceanography 28, 227-236.

Thiagarajan, N., Subhas, A.V., Southon, J.R., Eiler, J.M., 2014. Abrupt pre-Bolling-Allerod warming and circulation changes in the deep ocean. Nature.

Toggweiler, J.R., Russell, J.L., Carson, S.R., 2006. Midlatitude westerlies, atmospheric CO2, and climate change during the ice ages. Paleoceanography 21. doi:10.1029/2005PA001154

WAIS Divide Project Members, 2013. Onset of deglacial warming in West Antarctica driven by local orbital forcing. Nature 500, 440-444. doi:10.1038/nature12376

Wang, Y.J., cheng, H., Edwards, R.L., An, Z.S., Wu, J.Y., Shen, C.-C., Dorale, J.A., 2001. A High-Resolution Absolute-Dated Late Pleistocene Monsoon Record from Hulu Cave, China. Science 294, 2345-2348. doi:10.1126/science. 1064618

Yokoyama, Y., Lambeck, K., De Deckker, P., Johnston, P., Fifield, L.K., 2000. Timing of the Last Glacial Maximum from observed sea-level minima. Nature 406, 713-716. 